
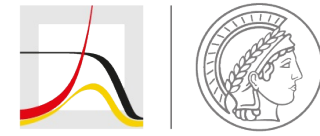

MAX PLANCK INSTITUTE

FOR DEMOGRAPHIC RESEARCH

Konrad-Zuse-Strasse 1 · D-18057 Rostock · Germany · Tel +49 (0) 3812081 - 0 · Fax +49 (0) 3812081 - $202 \cdot$ www.demogr.mpg.de

MPIDR Working Paper WP 2021-007 I April 2021

https://doi.org/10.4054/MPIDR-WP-2021-007

\title{
Lasting Effects of Parental Death during Childhood: Evidence from Sweden
}

Luis Serratos-Sotelo I luis.serratos@ekh.lu.se

Peter Eibich I eibich@demogr.mpg.de

(c) Copyright is held by the authors.

Working papers of the Max Planck Institute for Demographic Research receive only limited review. Views or opinions expressed in working papers are attributable to the authors and do not necessarily reflect those of the Institute. 


\title{
Lasting Effects of Parental Death during Childhood: Evidence from Sweden
}

\author{
Luis Serratos-Sotelo ${ }^{* 1,2,3}$ and Peter Eibich ${ }^{3}$ \\ ${ }^{1}$ Department of Economic History, Lund University \\ ${ }^{2}$ Centre for Economic Demography, Lund University \\ ${ }^{3}$ Max Planck Institute for Demographic Research
}

\begin{abstract}
This study looks at the effect of losing a parent before the age of 16 on adult income, educational attainment, and health. Using detailed data from the Swedish registers and several methodological strategies, we follow to adulthood individuals born between 1968 and 1981 and observe their later-life outcomes.

The results suggest that, in line with previous research, losing a parent during childhood is associated with substantively lower income, lower educational attainment and more hospitalizations. We find evidence of a critical phase from ages 6-15 for educational attainment and ages 2-10 for hospitalizations, and our estimates suggest that grief and parental investments are relevant mechanisms for the observed effects.
\end{abstract}

Keywords: parental death, early-life, income, education, hospitalization, Sweden

\footnotetext{
${ }^{*}$ Corresponding Author luis.serratos@ekh.lu.se. The authors would like to gratefully acknowledge suggestions and comments from Martin Dribe, Volha Lazuka, Tommy Bengtsson, Mikko Myrskylä, and Anton Nilsson. Financial support for this study from the Department of Economic History (Lund University) and the Max Planck Institute for Demographic Research is gratefully acknowledged.
} 


\section{Introduction}

Losing a parent is one of the greatest shocks any child can experience. Beyond the emotional grief and stress it generates, it can also have lasting implications to the family organization and to the resources (both human and material) available to the children during their development years. In Sweden, every year around 3000 children lose one or both their parents, which amounts to an estimated incidence rate of 1.5 per thousand 1 Hence, it is crucial for research to explore the effects that parental loss can have on adult outcomes. Moreover, the complex developmental trajectories during childhood suggest that the impact of parental loss depends on the age at which the child experiences bereavement. Understanding whether parental loss affects children more heavily at certain ages appears crucial for the development of interventions that can mitigate the disadvantage caused by early bereavement.

In this paper, we analyse the effect that losing a parent during childhood (up to the age of 15) has on adult income, educational attainment, and health. We also explore the notion of a critical period for parental loss, that is, we compare children who lost parents at different ages in order to examine whether there is one or several ages in which children's outcomes are more severely hit by losing a parent. Furthermore, we strengthen our comparison by controlling for family-level unobservables, like parenting styles, using a sibling approach that allows us to observe and contrast siblings who lost their parents at different point during their childhoods. Finally, we consider grief/emotional trauma and parental investments as relevant mechanisms and empirically test the relevance of these mechanisms based on hypotheses derived from the literature. The data for this study comes from the Swedish Interdisciplinary Panel (SIP), which consists of several population-based registers hosted at the Centre for Economic Demography at Lund University and administered by Statistics Sweden (Statistiska Centralbyrån, SCB). This high-quality administrative data allows us to identify all individuals born in Sweden between 1968 and 1981, who also lost a parent at some point during their life and then follow them to adulthood in order to observe their later-life outcomes. The data allows us to observe individuals until 2011, which means we are able to observe all our selected cohorts at least until the age of 30.

In line with the literature, the results show that there is a negative impact associated with losing a parent in early life on a child's adult income, educational attainment, and hospitalizations. We also find some evidence of particular critical periods in childhood, where losing a parent might be particularly disadvantaging. For instance, we find that losing a father in the first years of life (ages $0-1)$ has a greater negative impact on adult income; similarly losing a parent in early "school ages" $(2-5,6-10)$ is worse for a child's educational outcomes than other ages, while parental death in the 2-10 age range has a bigger impact on adult hospitalizations, and ages 6-10 seem to be the most relevant for adult mental health.

The rest of the paper is organized as follows: section 2 reviews the literature for early-life shocks and parental death, and presents the Swedish context; section 3 describes the Swedish register data and the samples used in the study while section 4 presents the methodological approaches employed in our analysis. We describe the results in section 5 while we discuss their implications more at detail in section 6 , finally, section 7 concludes.

\footnotetext{
${ }^{1}$ According to Statistics Sweden (SCB), around 3000 children lose their parents annually (2015-2018) which represents a 1.4-1.5 per thousand incidence rate. (https://www.scb.se/en/finding-statistics/statistics-by-subjectarea/population/population-composition/population-statistics/)
} 


\section{Theoretical Framework and Context}

The hypothesis that adult health and disease could be linked to early-life experiences was first proposed by Barker (1990). He found that alterations in maternal nutrition could alter their child's nutritional status during gestation and subsequently affect the child's risk from heart disease as an adult. The literature building on this idea that early-life (expanded to include not only gestation, but also the first years of life) is a critical period of development is abundant and has been systematically reviewed and summarized by Almond and Currie (2011), a summary that was recently updated by Almond et al. (2018).

For the particular case of Sweden, Bengtsson and Broström (2009) found that the disease environment in the first years of life has had long-lasting impacts on adult mortality as far back as the mid-nineteenth century. Bengtsson and Lindström (2000, 2003) found that the particular case of exposure to outbursts of airborne diseases can increase the mortality risk, especially from airborne diseases, in later life, even after controlling for food price variation (food resource availability) and maternal exposure to disease during pregnancy. Helgertz and Bengtsson (2019) analyzed the longterm effects of early-life exposure to the Spanish flu in 1918 and found that exposure resulted in higher morbidity (measured in hospitalizations) in later life, with males exposed also experiencing higher mortality risks from cancer and heart disease. Quaranta (2013) explored exposures to both economic and disease-related shocks in early-life in Sweden during the nineteenth and twentieth centuries. She found that higher food prices during the fetal period have a modest impact on landless males; however the effect of exposure to diseases (measles, scarlet fever, whooping cough) increases children's later-life mortality risk, with females exposed also having worse economic and reproductive outcomes. Recently, Lazuka (2018) found that a technological development could produce a positive shock in the child's health. She analyzed the introduction in Sweden of sulfa antibiotics to treat pneumonia in childhood and found that children exposed to this treatment had higher income and better health in later life, with the effect being similar among men and women.

Thus, there is ample evidence that early-life shocks (with varying definitions of the word "shock") are capable of having lasting or long-term impacts in those who suffer them, and that these impacts can be observed and assessed in different measures of adult or later-life outcomes. The reasons and mechanisms of these lasting effects differ among shocks, but there are a few that have been the subject of numerous studies.

One of these proposed explanations is that early-life shocks increase the stress experienced by children during their first years of life. Stress is assumed to accumulate throughout the life course, and elevated levels of it during the first years of life can be equated to having a disadvantageous start in a race, which explains why this effect can be felt and measured at different stages of life. Studies exploring this possibility have found that increased stress in childhood can be associated with a higher risk of suicide in later life (Brodsky, 2016), that higher levels of maternal stress while in utero can result in children with mental and motor developmental disadvantages (Huizink et al. 2003), that a childhood with more adversities and stress affects a girl's maternal abilities and even affects their children's school performance (Taylor et al. 2010), that elevated childhood stress due to family ruptures can lead to socioeconomic disadvantages in later life (Pesonen et al. 2011), or that early-life hardships can affect adults' self-reported health (Lindström et al. 2012) $:^{2}$

\footnotetext{
${ }^{2}$ While these studies share the same stress-focused framework, they operationalize stress shocks differently. Some
} 
A second mechanism to explain these lasting effects are resources. Research has found that an early-life shock can have long-lasting effects because it alters the amount or quality of the resources available to children during their development years. For instance, Hoddinott and Kinsey (2001) found that, in rural Zimbabwe households, experiencing a drought in the first two years of life can lead to a loss of height (a latent measure of health status) of up to $2 \mathrm{~cm}$, since it constrains the amount of food available to the children. Similarly, Schultz (2003) finds that, for the case of Ghana, childhood's nutritional and disease environment affects adult height, which in turn has a noticeable effect on adult income. Also, Maccini and Yang (2009) find that a prosperous environmental shock, in the form of abundant rainfall in early life, can increase the resources available and has a positive impact on the health, schooling, and socioeconomic performance of Indonesian women. This research has shown that while children all have capabilities to develop their human capital, the realization of this (sometimes genetic) potential is undeniably tied to the resources available to them during the developmental years of early childhood.

Following these theories, parental loss can also be considered an early-life shock with potentially lasting impacts throughout the life course. Losing a parent in early life has been found to negatively affect a variety of later-life outcomes, including mortality (Rostila et al. 2012), educational attainment (Barclay and Hällsten, 2019, Berg et al., 2014, Gertler et al., 2004, Kailaheimo and Erola, 2016. Prix and Erola, 2017) and occupational outcomes (Barclay and Hällsten, 2019). For the particular case of Sweden, research has shown that losing a parent in early life or childhood can have lasting effects on a educational attainment (Barclay and Hällsten, 2019, Berg et al., 2014), occupational choices (Barclay and Hällsten, 2019), mental health (Berg et al. 2016, Persson and Rossin-Slater 2018), self-injury behaviour (Rostila et al., 2016), and mortality (Rostila and Saarela, 2011).

The theoretical mechanisms behind these effects are closely related to those in the wider literature on early-life shocks. First, parental loss constitutes an emotional shock, which increases the amount of stress (in the form of grief and trauma) experienced by children during a critical phase in their lives. For example, Melhem et al. (2011) found that although grief induced by parental loss resolved within a year in most U.S. children in their study, about $10 \%$ of their sample showed a prolonged grief reaction at 33 months after parental death. Such prolonged grief was associated with a higher risk of depression. In line with this, Berg et al. (2016) reported that parental loss during early life was associated with the risk of depression for Swedish adults. Moreover, two studies found that the death of a maternal parent during gestation negatively affected children's birth outcomes (Black et al. 2016) and adult mental health (Persson and Rossin-Slater, 2018), presumably due to grief-related stress exposure in-utero.

Second, the death of a parent might reduce both the financial resources of the household and the household's time budget as the surviving parent bears the responsibility for both childcare and earnings. Thus, losing a parent can lead to reduced parental investment into children with negative consequences for education, labour market outcomes or health (Barclay and Hällsten, 2019, Gertler et al. 2004). Several studies have reported a negative impact of parental loss on educational attainment at different levels (Barclay and Hällsten, 2019, Berg et al., 2014, Gertler et al., 2004, Kailaheimo

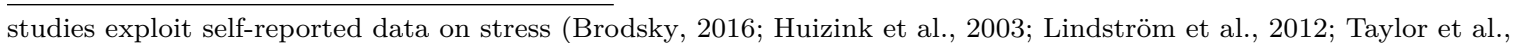
2010), others look at stressful events taking place in administrative data (Pesonen et al., |2011), while yet others analyze medical measures of cortisol, a stress-related hormone (Huizink et al.|2003). 
and Erola, 2016: Prix and Erola, 2017). Importantly, the parental investment mechanism has implications for the role of socioeconomic status (SES); losing a high SES parent implies a greater reduction of parental resources than the loss of a low SES parent, and therefore the impact of parental loss should be greater as well $3^{3}$ At the same time, reductions in parental investments might be compensated through other relatives or step-parents. While such differences by SES have received considerable attention in existing studies, the evidence remains inconclusive. For example, Prix and Erola (2017) reported that socioeconomic status of the deceased father only matters for the impact of bereavement on university entrances, and not for secondary education and entrance in polytechnics. In contrast, they found that socioeconomic status of the surviving mother served as a buffer against negative effects of paternal loss, but did not reduce the impact on university entrances. In contrast, Kailaheimo and Erola (2016) found that a reduction in family income did not contribute to their finding of a negative impact of parental loss on education. Moreover, step-parents did not compensate the negative impact of parental loss, which provides further evidence against the parental investment mechanism. Finally, Barclay and Hällsten (2019) find scattered evidence that the lost parent's educational or income levels regulate the effect of parental loss on the children's educational and occupational outcomes. They report some evidence for a protective effect of resources of the surviving parent or the extended family.

Third, it has been proposed that growing up in a non-traditional family structure may influence children's outcomes (Barclay and Hällsten, 2019 Corak 2001), and thus the impact of parental loss can be likened to divorce (Amato and Anthony, 2014, Corak, 2001). Much of the impact of a nontraditional family structure on children's outcomes likely comes from differences in financial resources and parental time investments (McLanahan and Percheski, 2008), and thus there is considerable overlap between the parental investment mechanism and the family structure mechanism. It is not clear whether the family structure should have a direct effect (i.e., independent of changes in parental investment) on children's outcomes. Gertler et al. (2004) mention the role of values and norms in intergenerational transmission of human capital. It is possible that the transmission of values and norms is directly affected by the family structure, independent of the amount of time and resources that parents invest in their children. Likewise and perhaps related, it might also be possible that step-parental investment is not a perfect substitute for time invested by a child's biological parents.

Disentangling these three mechanisms in practice is complicated, and few previous studies have provided empirical support for specific hypotheses (Barclay and Hällsten, 2019, Kailaheimo and Erola. 2016, Prix and Erola, 2017). In particular, identifying a direct effect of family structure independent of parental resources may not be possible. Nevertheless, the existing evidence allows us to derive specific hypotheses about the grief and parental investment mechanisms, which can be tested empirically.

First, we note that under all three mechanisms we might expect long-lasting effects on education, health and labour market outcomes. It might be plausible that a reduction in parental investment would primarily affect educational attainment, whereas grief and emotional stress primarily affect health. However, even if this were the case the close relationship between educational attainment and later life health suggests that long-run effects on all of these outcomes are plausible under all three mechanisms. Moreover, these mechanisms are not necessarily mutually exclusive. In addition, all three mechanisms generally suggest that younger children should be worse affected by parental loss than older children, because they suffer longer exposure to the mechanism in question. However,

\footnotetext{
${ }^{3}$ This would be true for non-monetary investments as well if parental education increases the productivity of, e.g., time investments.
} 
we argue that the grief mechanism implies that the effect of parental loss on educational attainment should be stronger for school-aged children than for younger children. Grief can be expected to have an immediate, disruptive effect on children's education, which might be long-lasting if children are not able to "catch up" or show a prolonged grief reaction. Melhem et al. (2011) suggest that the majority of children will cope with their grief within a year of losing a parent, which implies that most pre-school children will have already learned to adapt to the bereavement when they start school. Therefore, the short-term disruption of education for school-aged children should plausibly be larger than the long-term impact from prolonged grief. In addition, we would expect that the effect of parental loss operating through grief and emotional trauma should primarily affect mental health. Although grief might also plausibly affect other health outcomes, these effects should be less pronounced than the effect on mental health. Thus, when considering different measures of health we would expect the effect on measures of mental health to be more pronounced.

The parental investment mechanism has clear implications for the role of the deceased parent's SES and repartnering behaviour of the surviving parent. The loss of a high SES parent implies a larger loss in parental resources than the loss of a low SES parent, and therefore we should observe a clear SES gradient for the impact of parental loss. The surviving parent can offset the loss of resources by repartnering, and therefore a protective effect of repartnering suggests that parental investment plays an important role. Crucially, neither the deceased parent's SES nor the surviving parents' repartnering should have a direct impact on children's grief. At the same time, parental investment should matter equally for physical and mental health, and a lack of parental investment should follow a clear, monotonic age gradient. Thus, we can distinguish between grief/emotional trauma and parental investment by (i) examining the impact of parental loss by age of the child at exposure, (ii) examining mental health and physical health/general health separately, (iii) testing for heterogeneity by SES of the deceased parent, and (iv) testing for a protective effect of repartnering. As noted above, it is less clear how growing up in a non-traditional family structure would influence children's later-life outcomes directly (i.e., independent of parental investment), and we therefore cannot provide evidence for this mechanism.

Our paper contributes to the existing literature in a few ways. First, we focus on a variety of outcomes, including economic, educational, and health measures, giving a more rounded look of the impact of parental loss in childhood. Previous studies focused primarily on either health and mortality (Rostila and Saarela, 2011), education (Kailaheimo and Erola, 2016, Prix and Erola, 2017) or labour market outcomes (Barclay and Hällsten, 2019), whereas this is the first study to provide a comprehensive picture of the impact of parental loss. Second, this is the first study to provide suggestive evidence for the mechanisms through which parental loss affects children's laterlife outcomes. Although all three mechanisms outlined above are frequently discussed in previous studies, only the parental investment mechanism has been tested empirically (Barclay and Hällsten. 2019 Kailaheimo and Erola, 2016; Prix and Erola, 2017) with inconclusive results. Finally, we examine the existence of critical periods in childhood, during which losing a parent might have a larger effect on the child's later-life ${ }^{4}$ The literature on early-life shocks has long acknowledged the possible existence of critical periods, during which exposure to a shock has a stronger impact. Yet, this distinction has not yet been considered in the literature on parental death 5

\footnotetext{
${ }^{4}$ We divide the analysis of childhood years in several age groups, according to when parental loss occurred and categorize them following the standard practice in demographic analysis. Our age groups are (1) those aged 0-1, (2) those aged 2-5, (3) those aged 6-10, (4) those aged 11-15, and (5) those aged 16 and over.

5 Barclay and Hällsten (2019) allow for the effects of parental death to differ across age at death of the parent
} 


\section{Data}

The data for this study comes from the Swedish Interdisciplinary Panel (SIP), which is a compilation of population-based registers hosted at the Centre for Economic Demography at Lund University and administered by Statistics Sweden (Statistiska Centralbyrå, SCB). The longitudinal nature of the data allows us to identify all those who were born in Sweden between 1968 and 1981, who lost a parent at some point during their life and then follow them to adulthood in order to observe their later-life outcomes. The data allows us to observe individuals until 2011, which means that we are able to observe all our selected cohorts at least until the age of 30 .

The main exposure in our analysis is losing a parent during early life, which we define here as ages 0 to 15 , when most children are still not done with their formal education. Based on the different types of exposure possible, we create indicator variables for the following cases: (1) losing a mother in early life, (2) losing a father in early life, (3) losing either a mother or a father in early life, and (4) no loss of a parent before age 16. These different definitions should give us an idea of how the effect of parental loss varies based on the parent lost, or whether it is only the shock of losing a parent that matters for adult outcomes.

The outcomes included in this study are five. First, we observe the income of the individual at age 30. We choose age 30 for two reasons: It is the first age available for all the cohorts in our sample, and age 30 is often considered one of the earliest ages at which long-term effects of early-life events can be identified (Barclay and Hällsten, 2019). Second, we observe highest achieved education level, and we transform it to total years of education using the method described in Antelius and Björklund, 2000) 6 Finally, from the inpatient register we observe hospital admissions. From this data we created variables that reflect total number of hospitalizations, total days of hospitalization, and total number of hospitalizations related to mental health 17 These measures should allow us to distinguish between different aspects of poor adult health: (1) being hospitalized on several occasions throughout adulthood regardless of length of stay (i.e. poor long-term health, sick often, in and out of care), (2) spending longer amounts of time in hospital care regardless of number of admissions (i.e. having an accident or condition that requires several days attention), and (3) worse mental health due to grief/trauma experienced.

We also include in the analysis information about the child's sex, year of birth, and county of birth, to control for cohort, geographic, or gender-driven systematic differences in the outcomes. Information about parental education is included in the form of an indicator variable that takes the value of 1 if the parent(s) lost had more years of education than the mean ${ }^{8}$ In order to explore whether the repartnering behavior of the surviving parent acts as a compensation mechanism, we created a variable identifying those parents who, after the death of a partner (spouse or registered partner) went on to enter in a new marriage/registered partnership before their children turned 16.

\footnotetext{
by including a linear interaction term. However, this operationalization assumes that the effect of parental death is monotonous.

${ }^{6}$ Education in Sweden, according to the Education Act Skollag(2010:800), is compulsory for children between the ages of 6 and 15. The school years 1-9 are called grundskola in Swedish, and roughly correspond to elementary and middle school in the American-style systems $(6+3)$. After graduating, children may continue their education in the gymnasium, the Swedish term for high school (grades 10-12), which when finished grants access to higher education.

${ }^{7}$ Identified via ICD-9 codes 290-319 and ICD-10 codes F00-F99. Approximately 8\% of all hospitalizations in our sample fall in this category.

${ }^{8}$ For the cases of losing any parent, the same definition was applied here. That is, this variable would take the value of 1 if either parent had more education than the average parent.
} 
Detailed summary statistics of the variables included in the analysis, by type of parental death, can be seen in Table 1

\section{Methodological Approach}

Disentangling the effect of losing a parent in early life from all the possible confounders can be a challenging task. Our strategy for this study is threefold, and it aims at exploring the relationship between parental loss in early life and outcomes in later life, but from varying angles that would allow us to separate several known confounders in the relationship. First, we conduct a simple comparison by ordinary least squares (OLS), in which we regress the outcomes on the different exposures (parental loss) defined in the previous section. The model is of the form:

$$
Y_{i c t}=\beta_{0}+\beta_{1} \times \text { exposure }_{i}+\gamma X_{i}+\delta_{t}+\delta_{c}+\varepsilon_{i c t}
$$

Where $Y_{i c t}$ is any of the outcomes of interest (income, education, number/days/mental-health hospitalizations,) for individual $i$, born in county $c$ during year $t$, exposure is a dummy variable that takes the value of 1 if the individual $i$ lost a parent (different variables for mother, father, any) before the age of 16 and 0 otherwise. $X$ is a vector of individual-level controls that includes information on the individual's sex, the educational level of the lost parent relevant to the exposure, and the repartnering status of the surviving parent. $\delta_{c}$ and $\delta_{t}$ are fixed effects for year and county of birth, and $\varepsilon_{i c t}$ is the error term.

While the model in equation 1 is useful to provide a first insight into the relationship of interest here, it is unlikely that the estimates obtained through it would be unbiased. There might be, for instance, unobservable factors (captured in the error term) that affect the probability of a parent dying (and therefore of a child being exposed to such an event) that also affect the outcomes of interest. For example, parental occupation might affect the likelihood of work-related or traffic accidents as well as children's income through intergenerational transmission. Another reason for concern could be if, for instance, parents who die are systematically different from those who survive.

To try and avoid the endogeneity and unobservable factor issues described above, two strategies will be used in steps two and three of our approach. First, we will restrict the analysis to only those who we observe in the data that will end up losing a parent in the time frame studied. This means that we estimate the effect of parental loss in early life relative to losing one in later life. In this strategy, age groups $(0-1,2-5,6-10,11-15,16+)$ are used in order to compare differences in the effect of parental loss at different points in life. Given that all the individuals in this analysis will have lost a parent (either in early life or later), there should not be any remains of selective parental mortality $\left.\right|^{9}$

Finally, our strategy is to exploit timing differences in exposure across siblings ${ }^{10}$ Adding sibling fixed effects to our model effectively controls for unobservable characteristics that are shared at the

\footnotetext{
${ }^{9}$ Restricting the analysis to only those who have suffered a parental death in the observed time frame reduces our sample from 50,000-1,300,000 observation to around 10,000-300,000 observations, depending on the outcome and parent lost.

${ }^{10}$ In this case, we define siblings as those individuals who share the same mother, and we use the ID of the mother to link families together. This is done for completeness, since less individuals have missing values on Mother ID than Father ID.
} 
family level, like unobserved parental characteristics (Barclay and Hällsten, 2019). Our aim in this step is to identify children who lost a parent in early life, who have either younger or older siblings, and to exploit the age-difference at exposure to produce causal estimates of the effect of parental death at a specific stage in early-life on adult outcomes. One limitation of this approach is that it does not allow us to identify the effects of parental loss that are felt equally at all ages, and therefore the results of the sibling fixed effects approach should not necessarily be considered as definitive, rather they complement the findings from our earlier analyses by addressing additional sources of bias at the cost of a more narrow interpretation of the results.

\section{Results}

The results for the OLS regressions for the effect of exposure to parental death in early-life on adult outcomes are presented in Tables 26. In Table 2, we can observe the effect of losing a parent on adult income. In our models, losing a mother in early life is associated with a decrease in adult income of about $16 \%$, while losing a father in early-life is associated with an adult income that is $18-19 \%$ lower on average. Losing any parent before the age of 16 , regardless of which one it is who dies, is associated with a decrease in adult income of about $16-18 \%$ on average. Losing a highly educated parent does not seem to affect earnings above and beyond the overall impact of parental loss. We also do not find evidence of a protective effect of repartnering of the surviving parent - in contrast, we observe that children whose mothers repartner before the age of 16 suffer a higher income penalty from losing a father than children whose mothers did not repartner. One explanation for this counterintuitive result could be unresolved selection bias. In our sample, only $2.6 \%$ of widowed mothers repartnered before their child turned 16. It is plausible that this small proportion of the sample shares unobserved characteristics, which cause a higher income penalty.

The effect of parental loss on educational achievement can be seen in Table 3 Our models show that loss of a mother in early life is associated with achieving 0.31-0.34 less total years of education, equivalent to $18-20 \%$ of a standard deviation or $3.7-4.1$ months less of education. The corresponding association for losing a father is of $0.25-0.36$ less total years of education, equivalent to $14-21 \%$ of a standard deviation or 3.0-4.3 months in the schooling system. Finally, losing either parent before the age of 16 is associated with a decrease in total years of education of about $0.25-0.36$ years, on average. There is also evidence that losing early a parent with above average education is worse for the children's own educational attainment. Additionally, there is some evidence that a compensation mechanism might exist. Those children who lost a mother early, and whose surviving father repartnered before they turned 16 had better educational prospects than those whose father did not repartner or did so when his children were over the age of 16 . We estimate that, in this case, the repartnering behavior of the father mitigated almost $50 \%$ of the negative effect that losing a mother in early life had on the child's educational attainment. The lack of effect of a mother repartnering after the death of a father might point towards a heightened importance of regaining a maternal figure in childhood (as a consequence of a repartnering father), which is not equally true for paternal figures. It might also be due to the fact that, in our sample, widowing fathers repartnered early at a rate that was over 4 times that of mothers (11.4\% of the widowed fathers in our sample repartnered before their children turned 16 , compared to only $2.6 \%$ of widowed mothers).

The results of our models for the effect of parental loss on adult health, measured by days and 
number of hospitalizations, and by hospitalizations related to mental health can be seen in Tables 4 through 6. While our model present very stable results across the board for number of hospitalizations, it does less so for days of hospitalization, which we attribute to the large dispersion of the data in this variable. For number of hospitalizations, our models show that losing a parent in early life is associated with roughly half an extra hospitalization (our coefficients range from 0.493 to 0.572 ) in later life, equivalent to an increase of about $8 \%$ of a standard deviation. For the case of days of hospitalization, our models show that losing a parent in early life is associated with an increase of between 6.0 and 7.6 extra days of hospitalization. If the father is lost in early life, this is associated with an increase in hospitalization days of around 7 days, while the increase for losing a mother is between 5.6 and 6.8 days, but this result lacks statistical significance in our specifications. Finally, For the case of hospitalizations related to mental health, our models show that losing a parent in early life is associated with an increase of between 0.52 and 0.63 hospitalizations. Again, we do not find any statistically significant effects for losing a highly educated parent or for repartnering of the surviving parent.

The results for the models with age-groups analysis are presented in Tables 7] 11 below. It is important to keep in mind that these results speak of a relative effect of age at parental loss, instead of the direct or total effect/correlate described in the previous strategy. In these models, the coefficients should be interpreted as the effect of losing a parent in a particular age group relative to losing a parent in a different age group (our reference group in the models below is comprised of those who lost a parent over the age of 16$)$.

Table 7 shows the relative effect of parental loss in early life on adult income. The most complete specifications (models 3,6 and 9) seem to suggest that losing a father in early life (before 16) is associated with a reduced income at age 30, with this reduction being bigger for paternal losses of younger children and less so for older children. In this sense, the income loss associated with losing a father in early life is of around $20 \%$ if the loss happened in ages $0-1,9 \%$ if it happened in ages $6-10$, and $6.7 \%$ if it was during ages 11-15. The results also suggest that there losing a mother in ages 6-10 is associated with a loss in adult income of around 13\%, with all other age groups showing no statistically significant income differences associated with losing a mother in those groups (0-1, 2-5, 11-15) compared to losing her after age 16. The results for column (9), where the parental loss is codified as "first parent lost" are heavily mirroring the results from losing a father, which is explained by the fact that this is a more common occurrence. As before, we do not find differences for children losing a highly educated parent. Moreover, repartnering of the surviving mother is no longer statistically significant.

Table 8 shows the relative effect of parental loss in early life on educational achievement. Our models show that losing a mother in the age groups 2-5 or 6-10 is associated with a reduction in years of schooling of around 0.07-0.16 years (or approximately 1-2 months). Having a mother with aboveaverage education is associated with almost an entire extra year of schooling for her children, while losing an educated mother (in ages 6-10 and 11-15) is associated with a reduction of 0.11-0.22 years (or 1.3-2.6 moths) of schooling. As was the case with our first specification, this model also shows a beneficial effect if the surviving father repartners early, with the associated increase in education due to repartnering being around 3 months of schooling. For the case of losing a father, our models show that paternal loss in school ages $(6-10,11-15)$ is associated with a modest decrease in years of schooling of around 0.08-0.10 years (or around 1 month). Similarly to maternal loss, having an 
educated father proves beneficial for the children (increase of 10.3 months of schooling) while losing an educated father is detrimental for those who experience it at ages 0-1 (2.7 months less), 2-5 (3.24 months less), and 11-15 (1.32 months less).

The relative effect of parental loss in early life on hospitalizations are shown in Table 9 From our preferred specifications (columns 3,6, and 9) it is observed that there seems to be a health disadvantage associated with experiencing a maternal loss in the 2-5 age group. Those who lost their mothers while in this age group experienced around 0.52 more hospitalizations than those who lost their mothers after age 16. Losing a father early in life seems to be associated with an increase in hospitalizations of between 0.38-0.40, if the loss happened in the 2-5 or 6-10 age groups, compared to those who lost their fathers after the age of 16 . Looking at length of hospitalizations instead, as is shown in Table 10, we can appreciate an increase of 11 days of hospitalizations associated with losing a mother between the ages of 2 and 5 , relative to those who lost their mother later in life. The associated increase in days of hospitalization for losing a father is of around 6.4-8.1 days for those who lost a father in ages 2-5 and 6-10 respectively. Once more, this effect of paternal death is mirrored in the model that studies the first parent to be lost in column (9). In this last model we can see that losing a parent (any parent) in ages 2-5 is associated with an increase of 8.82 days of hospitalization, and losing them in ages 6-10 with a 4.63 days increase, compared to those who lost a parent in ages 16 and up. Focusing on hospitalizations related to mental health, we can observe in Table 11 that losing a father in ages 6-10 is associated with an increase of 1.2 hospitalizations. Furthermore, if the parent lost in those ages had above-average educational attainment, that increase rises by a further 1.7 hospitalizations. No significant effects could be found for maternal loss in this outcome, which might be related the reduced sample size, and the results for any parental loss mirror those of losing a father.

Our third and last strategy uses sibling-fixed effects and differences in the age at parental death to compare the effect of parental loss among siblings of different ages. By comparing only siblings, we are controlling for all unobserved characteristics that vary at the family-level, such as parenting styles, abilities, genetic factors, etc. The results, presented in Tables 12 16 below, are to be read as the effect of losing a parent on the outcomes, relative to an older sibling who experienced the loss later in life. Interestingly enough, when we employ the sibling approach in our analysis, the results seem to point very firmly in the same direction for all outcomes: there is generally no negative effects of losing a parent in early life, relative to losing them in older ages. This does not mean that losing a parent is not a damaging experience, but it does imply that it is not more damaging for certain outcomes when it happens in the ages between 0-15, than it is when it happens after the age of 16 . The notable exception here occurs when looking at the effects of losing a father on mental health hospitalizations. As our second specification showed, losing a father in ages 6-10 seems to be worse than losing him in other age groups. This is further confirmed when looking at siblings, where paternal death during ages 6-10 leads to a considerable increase of 4.4 hospitalizations due to mental-health.

\section{Discussion}

We examined the long-term consequences of parental loss in childhood on income, education and health using three different empirical approaches. Comparing individuals who lost a parent in childhood to those who did not experience parental loss, we found a strong and highly significant negative 
association for income, education and the number of hospitalizations. Estimates for losing a mother and losing a father were qualitatively similar and highly significant. For inpatient days, we found significant effects for losing a father, while the estimates for loss of a mother were imprecisely estimated.

While these results might suggest the presence of negative long-term effects of parental loss, they should be interpreted with caution. Parental loss during childhood is a rare event - only $3 \%$ of individuals in our sample lost a parent before the age of 16. Consequently, individuals who experienced parental loss during childhood are likely to be a highly select group. In particular, they are likely to come from disadvantaged families 11 For example, parents with a lower socioeconomic status are more likely to work in manual occupations with a higher risk of occupational accidents and injuries, which might be further compounded in informal and precarious work arrangements. Similarly, mortality from external causes or substance abuse is higher in disadvantaged and deprived neighborhoods (Sasson, 2016; Seaman et al. 2019). Social and economic disadvantage is transmitted across generations (Lundborg et al. 2018), and it is thus possible that the negative effects of losing a parent during childhood in our first model are driven by selection effects caused by the overrepresentation of individuals from disadvantaged families in the group experiencing parental loss.

Therefore, we estimated a second model, which compares individuals who lost a parent during childhood to individuals who experienced parental loss later in life, i.e., in young adulthood and mid-life. We found negative and significant effects of parental loss for all five outcomes. The point estimates for losing a mother and losing a father were often similar, although estimates for losing a father were in some cases more precisely identified. While there is no clear age gradient for income, our results for education and hospitalizations suggests the presence of a "critical" phase, during which parental loss has a more severe effect than at other ages. Specifically, we find that children losing a father between the ages of 6-15 and those losing a mother between the ages of 2-10 have significantly lower educational attainment than those losing a father or mother at earlier or later ages. For allcause hospitalizations, we found that losing a father matters most for children aged 2-10, and losing a mother matters most for children aged 2-5. We find only weakly significant effects for mental health hospitalizations.

An important caveat is that individuals losing a parent in childhood likely still differ from those losing a parent in young adulthood with respect to both observable and unobservable characteristics. While it seems plausible that these differences are less pronounced than those in our first model, we cannot rule out the presence of a bias. We therefore estimated a third specification, which compared siblings who lost their parent at different ages during childhood to each other.

However, we only found a marginally statistically significant increase in mental health hospitalizations for children losing a father between the ages 6-10. We also found weakly significant effects on education and all-cause hospitalizations, which went into the opposite direction as expected. Thus, these estimates should perhaps be considered as statistical artifacts. Nevertheless, this shouldn't be interpreted as evidence against a negative impact of parental loss, since all estimates are relative to siblings who lost a parent during young adulthood. Instead, it means that younger and older children as well as young adults are equally affected by the loss of a parent. The sibling design employed here is simply not suited to detect the absolute effects of losing a parent. Moreover, our estimates are only

\footnotetext{
${ }^{11}$ Children who lost a parent before the age of 16 are, for instance, $15 \%$ more likely to have a low-educated parent than those who did not experience parental loss.
} 
identified by siblings who lost a parent at different ages. Thus, while some of the point estimates are indeed substantial (in particular for losing a mother), our models lack statistical power to detect small or medium sized effects.

Turning to the mechanisms through which parental loss in early life affects later-life outcomes, we argue that our findings lend modest support to both mechanisms under consideration. First, our results for education are indicative of a critical phase for parental loss during early childhood. For example, we found that losing a father matters most for education between the ages of 6-15. Similarly, the effects for losing a mother on education are most pronounced for children who experience bereavement between the ages of 2-10. This could suggest that parental loss has a disruptive effect on children's education, which permanently disadvantages the affected children. Such a disruptive effect would be in line with our expectations on the impact of grief and emotional trauma. Similarly, we find a strong and significant effect on mental health hospitalizations, which in most models is larger and more precisely estimated than the impact on all-cause hospitalizations. Grief and emotional trauma might also explain why we did not find significant differences between siblings, since both grief and emotional trauma abate over time as most children learn to cope with their distress within a year (Melhem et al. 2011). Shorter periods of grieving might still have long-lasting effects by, e.g., disrupting children's education, however, the effects would not accumulate over time, such that the impact would not differ much for siblings that are relatively close in age. Rather, grief would affect siblings in a similar manner, and our sibling fixed effects model does not allow us to identify such absolute effects.

Second, we also find limited support for the parental investment mechanism. Losing a highly educated parent exacerbates the impact of parental loss on schooling, and the impact of losing a mother in early childhood on education can be mitigated if the surviving father repartners early. It is perhaps not surprising that parental investment seems to matter more for education than for income or health. We might expect that parental investment primarily impacts education, and the effects on income and health occur, at least partially, indirectly through the effects on education. Yet, it also suggests that the importance of the parental investment mechanism is rather limited, which is in line with conclusions drawn in earlier studies (Barclay and Hällsten, 2019, Kailaheimo and Erola, 2016 Prix and Erola, 2017).

A third mechanism, which has been proposed in earlier studies (Barclay and Hällsten, 2019), is the impact of growing up in a non-traditional family structure. There is considerable overlap between this mechanism and parental investment, and it is not clear that a non-traditional family structure should exert an impact on children's outcome independent of parental investment. We therefore did not empirically examine this mechanism separately. Crucially, disentangling parental investments and the direct impact of non-traditional family structures likely requires direct measures of parent's and step-parent's investments as well as their norms and values, which were not available in our data.

Finally, we note that we cannot rule out that our estimates of the impact of parental loss in early life are confounded by unobserved characteristics of families in which an early parental death occurs. Our sibling approach suggests that the estimates of losing a father in particular might be considerably smaller when comparing siblings in different age groups rather than children from different families. However, these estimates are identified by a smaller number of observations, since most siblings observed in our data tend to lose their parent while in the same age group. In addition, the sibling approach can only identify the effect of parental bereavement at a certain age relative to older or 
younger siblings. Hence, we cannot draw any conclusions on whether, e.g., the substantial reduction in income across all age groups is driven by selection or truly represents a causal effect.

Therefore, we recommend that future research should examine the characteristics of families in which an early parental death occur with rich household microdata to establish whether the socioeconomic background of children losing a parent beyond the age of 16 is comparable to those losing a parent at earlier ages. Likewise, investigating potential mechanisms in more depths, e.g., behavior of the affected children or their interactions with step-parents might yield important insights into the question to which extent the associations observed in our second model can be interpreted as causal.

\section{Conclusion}

In this paper, we analysed how the loss of a parent in early-life affected the bereaved children's income, educational attainment, and health (as measured by days and number of all-cause and mental health hospitalizations) during adulthood. Using high-quality administrative data from Swedish registers and a three-step econometric methodology that included sibling fixed-effects, we find that, in line with earlier studies (Berg et al., 2014, Barclay and Hällsten, 2019) losing a parent during childhood is associated with substantively lower income, educational attainment and more hospitalizations. We find evidence of a critical phase from ages 6-15 for educational attainment and ages 2-10 for hospitalizations, and we find suggestive evidence that grief and emotional trauma and (to a lesser extent) changes in parental investment are relevant mechanism behind these observed effects. Further research is, however, needed to address selective parental mortality, in order to shed light over the true causality of these estimates.

\section{References}

Almond, D. and Currie, J. (2011). Killing me softly: The fetal origins hypothesis. Journal of economic perspectives, 25(3):153-72.

Almond, D., Currie, J., and Duque, V. (2018). Childhood Circumstances and Adult Outcomes: Act II. Journal of Economic Literature, 56(4):1360-1446.

Amato, P. R. and Anthony, C. J. (2014). Estimating the effects of parental divorce and death with fixed effects models. Journal of Marriage and Family, 76(2):370-386.

Antelius, J. and Björklund, A. (2000). How reliable are register data for studies of the return on schooling? An examination of Swedish data. Scandinavian Journal of Educational Research, 44(4):341-355.

Barclay, K. J. and Hällsten, M. (2019). Socioeconomic variation in child educational and socioeconomic attainment after parental death in Sweden. Technical report, Max Planck Institute for Demographic Research, Rostock, Germany.

Barker, D. J. P. (1990). Fetal and infant origins of adult disease. British Medical Journal, 301(6761):1111.

Bengtsson, T. and Broström, G. (2009). Do conditions in early life affect old-age mortality directly and indirectly? Evidence form 19th-century rural Sweden. Social Science and Medicine, 68(9Online 13 March 2009):1583-1590. 
Bengtsson, T. and Lindström, M. (2000). Childhood misery and disease in later life: The effects on mortality in old age of hazards experienced in early life, southern Sweden, 1760-1894. Population Studies, 54(3):263-277.

Bengtsson, T. and Lindström, M. (2003). Airborne infectious diseases during infancy and mortality in later life in southern Sweden, 1766-1894. International Journal of Epidemiology, 32(2):286-294.

Berg, L., Rostila, M., and Hjern, A. (2016). Parental death during childhood and depression in young adults-a national cohort study. Journal of child psychology and psychiatry, 57(9):1092-1098.

Berg, L., Rostila, M., Saarela, J., and Hjern, A. (2014). Parental death during childhood and subsequent school performance. Pediatrics, 133(4):682-689.

Black, S. E., Devereux, P. J., and Salvanes, K. G. (2016). Does grief transfer across generations? Bereavements during pregnancy and child outcomes. American Economic Journal: Applied Economics, 8(1):193-223.

Brodsky, B. S. (2016). Early childhood environment and genetic interactions: the diathesis for suicidal behavior. Current psychiatry reports, 18(9):86.

Corak, M. (2001). Death and divorce: The long-term consequences of parental loss on adolescents. Journal of Labor Economics, 19(3):682-715.

Gertler, P., Levine, D. I., and Ames, M. (2004). Schooling and parental death. Review of Economics and Statistics, 86(1):211-225.

Helgertz, J. and Bengtsson, T. (2019). The Long-Lasting Influenza: The Impact of Fetal Stress During the 1918 Influenza Pandemic on Socioeconomic Attainment and Health in Sweden, 1968-2012. Demography, 56(4):1389-1425.

Hoddinott, J. and Kinsey, B. (2001). Child growth in the time of drought. Oxford Bulletin of Economics and statistics, 63(4):409-436.

Huizink, A. C., Robles de Medina, P. G., Mulder, E. J., Visser, G. H., and Buitelaar, J. K. (2003). Stress during pregnancy is associated with developmental outcome in infancy. Journal of Child Psychology and Psychiatry, 44(6):810-818.

Kailaheimo, S. and Erola, J. (2016). The effect of early parental death on children's university education. Working Papers on Social and Economic Issues, 12:2016.

Lazuka, V. (2018). The long-term health benefits of receiving treatment from qualified midwives at birth. Journal of Development Economics, 133:415-433.

Lindström, M., Hansen, K., and Rosvall, M. (2012). Economic stress in childhood and adulthood, and self-rated health: a population based study concerning risk accumulation, critical period and social mobility. BMC Public Health, 12(1):761.

Lundborg, P., Nordin, M., and Rooth, D. O. (2018). The intergenerational transmission of human capital: the role of skills and health. Journal of Population Economics, 31(4):1035-1065.

Maccini, S. and Yang, D. (2009). Under the weather: Health, schooling, and economic consequences of early-life rainfall. American Economic Review, 99(3):1006-26. 
McLanahan, S. and Percheski, C. (2008). Family structure and the reproduction of inequalities. Annu. Rev. Sociol, 34:257-276. Publisher: Annual Reviews.

Melhem, N. M., Porta, G., Shamseddeen, W., Walker Payne, M., and Brent, D. A. (2011). Grief in Children and Adolescents Bereaved by Sudden Parental Death. Archives of General Psychiatry, 68(9):911-919.

Persson, P. and Rossin-Slater, M. (2018). Family ruptures, stress, and the mental health of the next generation. American economic review, 108(4-5):1214-52.

Pesonen, A.-K., Räikkönen, K., Kajantie, E., Heinonen, K., Osmond, C., Barker, D. J., Forsen, T., and Eriksson, J. G. (2011). Inter-generational social mobility following early life stress. Annals of medicine, 43(4):320-328.

Prix, I. and Erola, J. (2017). Does death really make us equal? Educational attainment and resource compensation after paternal death in Finland. Social science research, 64:171-183.

Quaranta, L. (2013). Scarred for Life. How conditions in early life affect socioeconomic status, reproduction and mortality in Southern Sweden, 1813-1968. PhD thesis, Lund University (Media-Tryck).

Rostila, M., Berg, L., Arat, A., Vinnerljung, B., and Hjern, A. (2016). Parental death in childhood and self-inflicted injuries in young adults-a national cohort study from Sweden. European child \& adolescent psychiatry, 25(10):1103-1111.

Rostila, M., Saarela, J., and Kawachi, I. (2012). Mortality in parents following the death of a child: a nationwide follow-up study from Sweden. J Epidemiol Community Health, 66(10):927-933.

Rostila, M. and Saarela, J. M. (2011). Time does not heal all wounds: Mortality following the death of a parent. Journal of marriage and family, 73(1):236-249.

Sasson, I. (2016). Diverging Trends in Cause-Specific Mortality and Life Years Lost by Educational Attainment: Evidence from United States Vital Statistics Data, 1990-2010. PLOS ONE, 11(10):116.

Schultz, T. P. (2003). Wage rentals for reproducible human capital: evidence from Ghana and the Ivory Coast. Economics \& Human Biology, 1(3):331-366.

Seaman, R., Riffe, T., Leyland, A. H., Popham, F., and Raalte, A. v. (2019). The increasing lifespan variation gradient by area-level deprivation: A decomposition analysis of Scotland 1981-2011. Social Science \& Medicine, 230:147 - 157.

Taylor, Z. E., Larsen-Rife, D., Conger, R. D., Widaman, K. F., and Cutrona, C. E. (2010). Life stress, maternal optimism, and adolescent competence in single mother, African American families. Journal of family psychology, 24(4):468. 
Table 1: Summary Statistics

\begin{tabular}{|c|c|c|c|c|c|c|c|c|}
\hline & \multirow{3}{*}{ Full Sample } & \multicolumn{7}{|c|}{ Subsample 1: Only those with Parental Loss } \\
\hline & & \multirow[b]{2}{*}{ Parent Lost: } & \multicolumn{3}{|c|}{ Early Loss (Age $0-15)$} & \multicolumn{3}{|c|}{ Late Loss (Age 16+) } \\
\hline & & & Mother & Father & Any & Mother & Father & Any \\
\hline Ln(Income at Age 30$)$ & $\begin{array}{l}11.71 \\
(2.38)\end{array}$ & & $\begin{array}{l}11.55 \\
(2.55)\end{array}$ & $\begin{array}{l}11.53 \\
(2.58)\end{array}$ & $\begin{array}{l}11.53 \\
(2.58)\end{array}$ & $\begin{array}{l}11.65 \\
(2.30)\end{array}$ & $\begin{array}{l}11.64 \\
(2.33)\end{array}$ & $\begin{array}{l}11.65 \\
(2.33)\end{array}$ \\
\hline Total Years of Education & $\begin{array}{l}12.12 \\
(1.68)\end{array}$ & & $\begin{array}{l}11.77 \\
(1.69)\end{array}$ & $\begin{array}{l}11.76 \\
(1.70)\end{array}$ & $\begin{array}{l}11.76 \\
(1.70)\end{array}$ & $\begin{array}{l}11.81 \\
(1.67)\end{array}$ & $\begin{array}{l}11.85 \\
(1.68)\end{array}$ & $\begin{array}{l}11.86 \\
(1.67)\end{array}$ \\
\hline Total Hospitalizations (1990-2012) & $\begin{array}{c}3.47 \\
(4.93)\end{array}$ & & $\begin{array}{l}3.99 \\
(5.68)\end{array}$ & $\begin{array}{l}3.98 \\
(5.78)\end{array}$ & $\begin{array}{l}3.97 \\
(5.75)\end{array}$ & $\begin{array}{l}3.96 \\
(6.03)\end{array}$ & $\begin{array}{l}3.79 \\
(5.53)\end{array}$ & $\begin{array}{l}3.80 \\
(5.57)\end{array}$ \\
\hline Total Days of Hospitalization & $\begin{array}{c}18.50 \\
(283.20)\end{array}$ & & $\begin{array}{l}26.00 \\
(373.31)\end{array}$ & $\begin{array}{l}25.77 \\
(243.02)\end{array}$ & $\begin{array}{l}25.50 \\
(289.32)\end{array}$ & $\begin{array}{l}22.68 \\
(385.16)\end{array}$ & $\begin{array}{l}22.11 \\
(313.72)\end{array}$ & $\begin{array}{l}22.03 \\
(313.20)\end{array}$ \\
\hline $\begin{array}{l}\text { Total Hospitalizations } \\
\text { related to Mental Health }\end{array}$ & $\begin{array}{c}3.90 \\
(7.63)\end{array}$ & & $\begin{array}{l}4.50 \\
(8.00)\end{array}$ & $\begin{array}{l}4.43 \\
(7.86)\end{array}$ & $\begin{array}{l}4.43 \\
(7.92)\end{array}$ & $\begin{array}{l}4.63 \\
(8.32)\end{array}$ & $\begin{array}{l}4.30 \\
(7.95)\end{array}$ & $\begin{array}{l}4.36 \\
(8.05)\end{array}$ \\
\hline $\begin{array}{l}\text { Surviving Parent repartnered } \\
\text { before child turned } 16(\%)\end{array}$ & $0.26 \%$ & & $11.36 \%$ & $2.56 \%$ & $5.43 \%$ & & & \\
\hline Child is female (\%) & $48.62 \%$ & & $48.52 \%$ & $48.57 \%$ & $48.56 \%$ & $48.14 \%$ & $48.45 \%$ & $48.40 \%$ \\
\hline Lost Parent w/ above avg. Schooling (\%) & & & $32.91 \%$ & $27.28 \%$ & $39.91 \%$ & $30.21 \%$ & $26.71 \%$ & $40.81 \%$ \\
\hline Birth Year (range 1968-1981) & $\begin{array}{c}1973.78 \\
(3.71)\end{array}$ & & $\begin{array}{l}1973.59 \\
(3.73)\end{array}$ & $\begin{array}{l}1973.41 \\
(3.71)\end{array}$ & $\begin{array}{l}1973.47 \\
(3.72)\end{array}$ & $\begin{array}{l}1972.35 \\
(3.49)\end{array}$ & $\begin{array}{l}1972.39 \\
(3.51)\end{array}$ & $\begin{array}{l}1972.49 \\
(3.53)\end{array}$ \\
\hline \multicolumn{9}{|l|}{ Age-Groups at Parental Loss } \\
\hline $0-1$ & & & 608 & 1,971 & 2,563 & & & \\
\hline $2-5$ & & & 2,188 & 5,392 & 7,517 & & & \\
\hline $6-10$ & & & 3,939 & 9,304 & 13,051 & & & \\
\hline $11-15$ & & & 5,809 & 12,709 & 18,161 & & & \\
\hline $16+$ & & & & & & 109,815 & 206,814 & 279,813 \\
\hline \multirow{4}{*}{$\begin{array}{l}\text { Number of Deaths observed } \\
N\end{array}$} & 321,105 & & 12.544 & 32.487 & 45.754 & 108341 & 203.703 & 283,226 \\
\hline & & \multicolumn{7}{|c|}{ Subsample 2: Sibling Approach } \\
\hline & & & \multicolumn{3}{|c|}{ Early Loss (Age 0-15) } & \multicolumn{3}{|c|}{ Late Loss (Age 16+) } \\
\hline & & Parent Lost: & Mother & Father & Any & Mother & Father & Any \\
\hline Ln(Income at Age 30) & & & $\begin{array}{l}11.57 \\
(2.54)\end{array}$ & $\begin{array}{l}11.53 \\
(2.60)\end{array}$ & $\begin{array}{l}11.54 \\
(2.59)\end{array}$ & $\begin{array}{l}11.66 \\
(2.32)\end{array}$ & $\begin{array}{l}11.65 \\
(2.35)\end{array}$ & $\begin{array}{l}11.66 \\
(2.35)\end{array}$ \\
\hline Total Years of Education & & & $\begin{array}{l}11.79 \\
(1.70)\end{array}$ & $\begin{array}{l}11.74 \\
(1.71)\end{array}$ & $\begin{array}{l}11.76 \\
(1.71)\end{array}$ & $\begin{array}{l}11.83 \\
(1.69)\end{array}$ & $\begin{array}{l}11.87 \\
(1.69)\end{array}$ & $\begin{array}{l}11.88 \\
(1.69)\end{array}$ \\
\hline Total Hospitalizations (1990-2012) & & & $\begin{array}{l}3.96 \\
(5.65)\end{array}$ & $\begin{array}{l}3.97 \\
(5.47)\end{array}$ & $\begin{array}{l}3.96 \\
(5.51)\end{array}$ & $\begin{array}{l}3.98 \\
(6.15)\end{array}$ & $\begin{array}{l}3.80 \\
(5.54)\end{array}$ & $\begin{array}{l}3.82 \\
(5.60)\end{array}$ \\
\hline Total Days of Hospitalization (1990-2012) & & & $\begin{array}{l}30.37 \\
(150.18)\end{array}$ & $\begin{array}{l}25.36 \\
(302.20)\end{array}$ & $\begin{array}{l}26.46 \\
(267.54)\end{array}$ & $\begin{array}{l}23.81 \\
(376.81)\end{array}$ & $\begin{array}{l}22.03 \\
(343.79)\end{array}$ & $\begin{array}{l}22.54 \\
(312.96)\end{array}$ \\
\hline $\begin{array}{l}\text { Total Hospitalizations } \\
\text { related to Mental Health }\end{array}$ & & & $\begin{array}{l}4.64 \\
(8.36)\end{array}$ & $\begin{array}{l}4.23 \\
(7.38)\end{array}$ & $\begin{array}{l}4.35 \\
(7.70)\end{array}$ & $\begin{array}{l}4.71 \\
(7.95)\end{array}$ & $\begin{array}{l}4.38 \\
(7.92)\end{array}$ & $\begin{array}{l}4.43 \\
(8.05)\end{array}$ \\
\hline Child is female (\%) & & & $49.03 \%$ & $48.76 \%$ & $48.89 \%$ & $48.12 \%$ & $48.50 \%$ & $48.43 \%$ \\
\hline Birth Year (range 1968-1981) & & & $\begin{array}{l}1974.25 \\
(3.53)\end{array}$ & $\begin{array}{l}1973.86 \\
(3.54)\end{array}$ & $\begin{array}{l}1973.97 \\
(3.55)\end{array}$ & $\begin{array}{l}1972.94 \\
(3.43)\end{array}$ & $\begin{array}{l}1972.94 \\
(3.44)\end{array}$ & $\begin{array}{l}1973.00 \\
(3.44)\end{array}$ \\
\hline Age-Groups at Parental Loss & & & & & & & & \\
\hline $0-1$ & & & 215 & 1,057 & 1,269 & & & \\
\hline $2-5$ & & & 1,071 & 3,147 & 4,178 & & & \\
\hline $6-10$ & & & 2,275 & 5,536 & 7,700 & & & \\
\hline $11-15$ & & & 3,515 & 7,515 & 10,866 & & & \\
\hline $16+$ & & & & & & 108,899 & 204,933 & 277,081 \\
\hline Number of Families* & & & 4,494 & 11,670 & 15,910 & 29,405 & 60,851 & 83,177 \\
\hline Number of Observations** & & & 7,992 & 19,136 & 26,745 & 63,216 & 120,748 & 170,279 \\
\hline
\end{tabular}

Source: Authors' calculations with data from Statistics Sweden (SCB)

Note: This table shows means and standard deviations (in parenthesis) for the variables included in the study. For some cases (marked next to the variable name) it shows number of events or percentages of the total (for dummy variables). Full sample includes full birth cohorts 1968-1981; subsample 1 is limited to those for whom parental death can be observed; subsample 2 further is further restricted to families with more than one child for which a parental death is observed. * Families are linked using Mother's ID. Since some families may have children in both the early and late loss groups, any one family can be included in both counts. ${ }^{* *}$ Maximum number of observations possible. The actual number included in each model is stated in the result tables and might be smaller to account for completeness (non-missing) of outcomes and covariates. 
Table 2: Effect on Adult Income of Losing a Parent in Early Life

\begin{tabular}{|c|c|c|c|c|c|c|c|c|c|}
\hline \multirow[t]{2}{*}{ Parent Lost: } & \multicolumn{3}{|c|}{ Mother } & \multicolumn{3}{|c|}{ Father } & \multicolumn{3}{|c|}{ "Any } \\
\hline & $(1)$ & $(2)$ & $(3)$ & $(4)$ & $(5)$ & $(6)$ & $(7)$ & $(8)$ & $(9)$ \\
\hline Ln(Income at Age 30) & $\begin{array}{l}-0.167 * * * \\
(0.0237)\end{array}$ & $\begin{array}{l}-0.160^{* * *} \\
(0.0253)\end{array}$ & $\begin{array}{l}-0.161^{* * *} \\
(0.0289)\end{array}$ & $\begin{array}{l}-0.186^{* * *} \\
(0.0156)\end{array}$ & $\begin{array}{l}-0.192^{* * *} \\
(0.0160)\end{array}$ & $\begin{array}{l}-0.173^{* * *} \\
(0.0175)\end{array}$ & $\begin{array}{l}-0.186^{* * *} \\
(0.0133)\end{array}$ & $\begin{array}{l}-0.186^{* * *} \\
(0.0137)\end{array}$ & $\begin{array}{l}-0.163^{* * *} \\
(0.0164)\end{array}$ \\
\hline $\begin{array}{l}\text { sex } \\
(1=\text { female })\end{array}$ & & $\begin{array}{l}-0.248^{* * *} \\
(0.00435)\end{array}$ & $\begin{array}{l}-0.248^{* * *} \\
(0.00435)\end{array}$ & & $\begin{array}{r}-0.245^{* * *} \\
(0.00423)\end{array}$ & $\begin{array}{l}-0.245^{* * *} \\
(0.00423)\end{array}$ & & $\begin{array}{l}-0.252^{* * *} \\
(0.00433)\end{array}$ & $\begin{array}{r}-0.252^{* * *} * \\
(0.00433)\end{array}$ \\
\hline $\begin{array}{l}\text { Mother's education } \\
\text { (1= above average attainment) }\end{array}$ & & $\begin{array}{l}-0.0821^{* * *} \\
(0.00476)\end{array}$ & & & & & & $\begin{array}{l}-0.0396^{* * *} \\
(0.00495)\end{array}$ & \\
\hline Mother's education * Parental Loss & & & $\begin{array}{l}0.00413 \\
(0.0547)\end{array}$ & & & & & & $\begin{array}{l}-0.0170 \\
(0.0331)\end{array}$ \\
\hline Father repartner early & & $\begin{array}{l}-0.0359 \\
(0.0619)\end{array}$ & $\begin{array}{l}-0.0362 \\
(0.0619)\end{array}$ & & & & & & $\begin{array}{l}-0.0246 \\
(0.0604)\end{array}$ \\
\hline $\begin{array}{l}\text { Father's education } \\
\text { (1= above average attainment) }\end{array}$ & & & & & $\begin{array}{l}-0.122^{* * *} \\
(0.00494)\end{array}$ & & & $\begin{array}{l}-0.109^{* * *} \\
(0.00525)\end{array}$ & \\
\hline Father's education * Parental Loss & & & & & & $\begin{array}{l}-0.0679 \\
(0.0395)\end{array}$ & & & $\begin{array}{l}-0.0402 \\
(0.0349)\end{array}$ \\
\hline Mother repartner early & & & & & $\begin{array}{c}-0.275^{* *} \\
(0.0933)\end{array}$ & $\begin{array}{c}-0.273^{* *} \\
(0.0933)\end{array}$ & & & $\begin{array}{c}-0.284^{* *} \\
(0.0968)\end{array}$ \\
\hline Controls (Birth Year / Birth County) & No & Yes & Yes & No & Yes & Yes & No & Yes & Yes \\
\hline $\mathrm{N}$ & 1276234 & 1125085 & 1125085 & 1276234 & 1191600 & 1191600 & 1276234 & 1097799 & 1097799 \\
\hline adj. R-sq & 0.000 & 0.006 & 0.006 & 0.000 & 0.006 & 0.006 & 0.000 & 0.007 & 0.007 \\
\hline
\end{tabular}

Source: Authors' calculations with data from Statistics Sweden (SCB)

Note: Heteroskedasticity-robust standard errors in parentheses. Where indicated, the models control for the individual's sex, birth year, birth county, the level of education of the lost parent, and for the repartnering behavior of the surviving parent. Early loss of a parent is interacted, where indicated, with the education of the lost parent.

${ }^{*} \mathrm{p}<0.05,{ }^{* *} \mathrm{p}<0.01,{ }^{* * *} \mathrm{p}<0.001$

Table 3: Effect on Years of Schooling of Losing a Parent in Early Life

\begin{tabular}{|c|c|c|c|c|c|c|c|c|c|}
\hline \multirow[t]{2}{*}{ Parent Lost: } & \multicolumn{3}{|c|}{ Mother } & \multicolumn{3}{|c|}{ Father } & \multicolumn{3}{|c|}{ "Any } \\
\hline & $(1)$ & $(2)$ & $(3)$ & $(4)$ & $(5)$ & $(6)$ & $(7)$ & $(8)$ & $(9)$ \\
\hline Years of Schooling & $\begin{array}{l}-0.349^{* * *} \\
(0.0154)\end{array}$ & $\begin{array}{l}-0.342^{* * *} \\
(0.0161)\end{array}$ & $\begin{array}{l}-0.314^{* * *} \\
(0.0189)\end{array}$ & $\begin{array}{l}-0.365^{* * *} \\
(0.0102)\end{array}$ & $\begin{array}{l}-0.304^{* * *} \\
(0.0103)\end{array}$ & $\begin{array}{l}-0.253^{* * *} \\
(0.0118)\end{array}$ & $\begin{array}{r}-0.363^{* * *} \\
(0.00860)\end{array}$ & $\begin{array}{c}-0.287^{* * *} \\
(0.00895)\end{array}$ & $\begin{array}{l}-0.248^{* * *} \\
(0.0110)\end{array}$ \\
\hline $\begin{array}{l}\operatorname{sex} \\
(1=\text { female })\end{array}$ & & $\begin{array}{l}0.465^{* * *} \\
(0.00297)\end{array}$ & $\begin{array}{l}0.465^{* * *} \\
(0.00297)\end{array}$ & & $\begin{array}{l}0.472^{* * *} \\
(0.00290)\end{array}$ & $\begin{array}{l}0.472^{* * *} \\
(0.00290)\end{array}$ & & $\begin{array}{l}0.466^{* * *} \\
(0.00295)\end{array}$ & $\begin{array}{l}0.466^{* * *} \\
(0.00295)\end{array}$ \\
\hline $\begin{array}{l}\text { Mother's education } \\
\text { (1= above average attainment) }\end{array}$ & & $\begin{array}{l}0.873^{* * *} \\
(0.00312)\end{array}$ & & & & & & $\begin{array}{l}0.646^{* * *} \\
(0.00335)\end{array}$ & \\
\hline Mother's education * Parental Loss & & & $\begin{array}{l}-0.0896^{* *} \\
(0.0341)\end{array}$ & & & & & & $\begin{array}{l}0.0329 \\
(0.0210)\end{array}$ \\
\hline Father repartner early & & $\begin{array}{l}0.150^{* * *} \\
(0.0380)\end{array}$ & $\begin{array}{l}0.156^{* * *} \\
(0.0380)\end{array}$ & & & & & $\begin{array}{l}0.0855^{*} \\
(0.0364)\end{array}$ & $\begin{array}{l}0.0975^{* *} \\
(0.0365)\end{array}$ \\
\hline $\begin{array}{l}\text { Father's education } \\
(1=\text { above average attainment) }\end{array}$ & & & & & $\begin{array}{l}0.906^{* * *} \\
(0.00315)\end{array}$ & & & $\begin{array}{l}0.674^{* * *} \\
(0.00346)\end{array}$ & \\
\hline Father's education * Parental Loss & & & & & & $\begin{array}{l}-0.187^{* * *} \\
(0.0237)\end{array}$ & & & $\begin{array}{l}-0.175^{* * *} \\
(0.0217)\end{array}$ \\
\hline Mother repartner early & & & & & $\begin{array}{l}-0.0733 \\
(0.0526)\end{array}$ & $\begin{array}{l}-0.0698 \\
(0.0526)\end{array}$ & & $\begin{array}{l}-0.0791 \\
(0.0530)\end{array}$ & $\begin{array}{l}-0.0766 \\
(0.0529)\end{array}$ \\
\hline Controls (Birth Year / Birth County) & No & Yes & Yes & No & Yes & Yes & No & Yes & Yes \\
\hline $\begin{array}{l}\mathrm{N} \\
\text { adj. R-sq }\end{array}$ & $\begin{array}{l}1304984 \\
0.000\end{array}$ & $\begin{array}{l}1149826 \\
0.097\end{array}$ & $\begin{array}{l}1149826 \\
0.097\end{array}$ & $\begin{array}{l}1304984 \\
0.001\end{array}$ & $\begin{array}{l}1217360 \\
0.094\end{array}$ & $\begin{array}{l}1217360 \\
0.094\end{array}$ & $\begin{array}{l}1304984 \\
0.001\end{array}$ & $\begin{array}{l}1121387 \\
0.130\end{array}$ & $\begin{array}{l}1121387 \\
0.130\end{array}$ \\
\hline $\begin{array}{l}\text { Source: Authors' calculations with data from } \\
\text { Note: Heteroskedasticity-robust standard err } \\
\text { education of the lost parent, and for the repar } \\
\text { lost parent. } \\
{ }^{*} \mathrm{p}<0.05,{ }^{* *} \mathrm{p}<0.01,{ }^{* * *} \mathrm{p}<0.001\end{array}$ & $\begin{array}{l}\text { Statistics Swe } \\
\text { ors in parentl } \\
\text { tnering behav }\end{array}$ & $\begin{array}{l}\text { len (SCB) } \\
\text { ses. Where } \\
\text { or of the sur }\end{array}$ & $\begin{array}{l}\text { dicated, the } \\
\text { ing parent. }\end{array}$ & $\begin{array}{l}\text { odels contro } \\
\text { arly loss of a }\end{array}$ & $\begin{array}{l}\text { for the indi } \\
\text { arent is inte }\end{array}$ & $\begin{array}{l}\text { ual's sex, } \\
\text { ted, where }\end{array}$ & $\begin{array}{l}\text { h year, birth } \\
\text { licated, with }\end{array}$ & $\begin{array}{l}\text { ounty, the l } \\
\text { he education }\end{array}$ & $\begin{array}{l}\text { el of } \\
\mathrm{f} \text { the }\end{array}$ \\
\hline
\end{tabular}


Table 4: Effect on Adult Hospitalizations of Losing a Parent in Early Life

\begin{tabular}{|c|c|c|c|c|c|c|c|c|c|}
\hline \multirow[t]{2}{*}{ Parent Lost: } & \multicolumn{3}{|c|}{ Mother } & \multicolumn{3}{|c|}{ Father } & \multicolumn{3}{|c|}{ Any } \\
\hline & $(1)$ & $(2)$ & $(3)$ & $(4)$ & $(5)$ & $(6)$ & $(7)$ & $(8)$ & $(9)$ \\
\hline Number of Adult Hospitalizations & $\begin{array}{l}0.502^{* * * *} \\
(0.0620)\end{array}$ & $\begin{array}{l}0.524^{* * * *} \\
(0.0660)\end{array}$ & $\begin{array}{l}0.572^{* * *} \\
(0.0809)\end{array}$ & $\begin{array}{l}0.541^{* * *} * \\
(0.0418)\end{array}$ & $\begin{array}{l}0.521^{* * *} \\
(0.0435)\end{array}$ & $\begin{array}{l}0.532^{* * *} \\
(0.0526)\end{array}$ & $\begin{array}{l}0.528^{* * *} \\
(0.0352)\end{array}$ & $\begin{array}{l}0.493^{* * *} \\
(0.0382)\end{array}$ & $\begin{array}{l}0.540^{* * *} \\
(0.0508)\end{array}$ \\
\hline $\begin{array}{l}\operatorname{sex} \\
(1=\text { female })\end{array}$ & & $\begin{array}{l}1.095^{* * *} * \\
(0.0115)\end{array}$ & $\begin{array}{l}1.095^{* * *} \\
(0.0115)\end{array}$ & & $\begin{array}{l}1.106^{* * *} \\
(0.0112)\end{array}$ & $\begin{array}{l}1.106^{* * *} \\
(0.0112)\end{array}$ & & $\begin{array}{l}1.104^{* * *} \\
(0.0116)\end{array}$ & $\begin{array}{l}1.104^{* * *} \\
(0.0116)\end{array}$ \\
\hline $\begin{array}{l}\text { Mother's education } \\
\text { (1= above average attainment) }\end{array}$ & & $\begin{array}{l}-0.409^{* * *} \\
(0.0111)\end{array}$ & & & & & & $\begin{array}{l}-0.322^{* * *} \\
(0.0118)\end{array}$ & \\
\hline Mother's education * Parental Loss & & & $\begin{array}{l}-0.155 \\
(0.128)\end{array}$ & & & & & & $\begin{array}{l}-0.128 \\
(0.0798)\end{array}$ \\
\hline Father repartner early & & $\begin{array}{l}-0.135 \\
(0.160)\end{array}$ & $\begin{array}{l}-0.126 \\
(0.161)\end{array}$ & & & & & $\begin{array}{l}-0.105 \\
(0.157)\end{array}$ & $\begin{array}{r}-0.0947 \\
(0.157)\end{array}$ \\
\hline $\begin{array}{l}\text { Father's education } \\
\text { (1= above average attainment) }\end{array}$ & & & & & $\begin{array}{l}-0.371^{* * *} \\
(0.0113)\end{array}$ & & & $\begin{array}{l}-0.242^{* * *} \\
(0.0122)\end{array}$ & \\
\hline Father's education * Parental Loss & & & & & & $\begin{array}{l}-0.0445 \\
(0.0895)\end{array}$ & & & $\begin{array}{l}-0.0302 \\
(0.0811)\end{array}$ \\
\hline Mother repartner early & & & & & $\begin{array}{l}0.271 \\
(0.197)\end{array}$ & $\begin{array}{l}0.272 \\
(0.197)\end{array}$ & & $\begin{array}{c}-0.0200 \\
(0.160)\end{array}$ & $\begin{array}{c}-0.0192 \\
(0.160)\end{array}$ \\
\hline Controls (Birth Year / Birth County) & No & Yes & Yes & No & Yes & Yes & No & Yes & Yes \\
\hline $\mathrm{N}$ & 873777 & 767395 & 767395 & 873777 & 814515 & 814515 & 873777 & 748757 & 748757 \\
\hline adj. R-sq & 0.000 & 0.016 & 0.016 & 0.000 & 0.015 & 0.015 & 0.000 & 0.017 & 0.017 \\
\hline
\end{tabular}


Table 5: Effect on Days of Hospitalization of Losing a Parent in Early Life

\begin{tabular}{|c|c|c|c|c|c|c|c|c|c|}
\hline \multirow[t]{2}{*}{ Parent Lost: } & \multicolumn{3}{|c|}{ Mother } & \multicolumn{3}{|c|}{ Father } & \multicolumn{3}{|c|}{ Any } \\
\hline & $(1)$ & $(2)$ & $(3)$ & $(4)$ & $(5)$ & $(6)$ & $(7)$ & $(8)$ & (9) \\
\hline Days of Hospitalization & $\begin{array}{l}6.805 \\
(4.305)\end{array}$ & $\begin{array}{l}6.345 \\
(5.096)\end{array}$ & $\begin{array}{l}5.623 \\
(7.122)\end{array}$ & $\begin{array}{l}7.651^{* * *} \\
(1.820)\end{array}$ & $\begin{array}{l}7.381^{* * * *} \\
(1.990)\end{array}$ & $\begin{array}{l}7.424^{* *} \\
(2.599)\end{array}$ & $\begin{array}{l}7.136^{* * *} \\
(1.836)\end{array}$ & $\begin{array}{l}6.046^{* *} \\
(2.177)\end{array}$ & $\begin{array}{l}5.430 \\
(3.321)\end{array}$ \\
\hline $\begin{array}{l}\text { sex } \\
(1=\text { female })\end{array}$ & & $\begin{array}{l}0.297 \\
(0.705)\end{array}$ & $\begin{array}{l}0.297 \\
(0.705)\end{array}$ & & $\begin{array}{l}0.365 \\
(0.669)\end{array}$ & $\begin{array}{l}0.365 \\
(0.669)\end{array}$ & & $\begin{array}{l}0.377 \\
(0.711)\end{array}$ & $\begin{array}{l}0.377 \\
(0.711)\end{array}$ \\
\hline $\begin{array}{l}\text { Mother's education } \\
\text { (1= above average attainment) }\end{array}$ & & $\begin{array}{l}-2.189^{* *} \\
(0.671)\end{array}$ & & & & & & $\begin{array}{l}-2.137^{* * * *} \\
(0.609)\end{array}$ & \\
\hline Mother's education * Parental Loss & & & $\begin{array}{l}2.347 \\
(7.039)\end{array}$ & & & & & & $\begin{array}{l}2.012 \\
(2.720)\end{array}$ \\
\hline Father repartner early & & $\begin{array}{l}0.804 \\
(4.607)\end{array}$ & $\begin{array}{l}0.666 \\
(4.370)\end{array}$ & & & & & $\begin{array}{l}1.010 \\
(3.566)\end{array}$ & $\begin{array}{l}0.884 \\
(3.489)\end{array}$ \\
\hline $\begin{array}{l}\text { Father's education } \\
(1=\text { above average attainment) }\end{array}$ & & & & & $\begin{array}{l}-1.212 \\
(0.646)\end{array}$ & & & $\begin{array}{l}-0.432 \\
(0.613)\end{array}$ & \\
\hline Father's education * Parental Loss & & & & & & $\begin{array}{l}-0.165 \\
(3.115)\end{array}$ & & & $\begin{array}{l}0.0524 \\
(2.572)\end{array}$ \\
\hline Mother repartner early & & & & & $\begin{array}{l}9.501 \\
(6.310)\end{array}$ & $\begin{array}{l}9.503 \\
(6.308)\end{array}$ & & $\begin{array}{l}7.541 \\
(6.456)\end{array}$ & $\begin{array}{l}7.532 \\
(6.454)\end{array}$ \\
\hline Controls (Birth Year / Birth County) & No & Yes & Yes & No & Yes & Yes & No & Yes & Yes \\
\hline $\mathrm{N}$ & 873777 & 767395 & 767395 & 873777 & 814515 & 814515 & 873777 & 748757 & 748757 \\
\hline adj. R-sq & 0.000 & 0.002 & 0.002 & 0.000 & 0.001 & 0.001 & 0.000 & 0.002 & 0.002 \\
\hline
\end{tabular}


Table 6: Effect on Mental Health Hospitalizations of Losing a Parent in Early Life

\begin{tabular}{|c|c|c|c|c|c|c|c|c|c|}
\hline \multirow[t]{2}{*}{ Parent Lost: } & \multicolumn{3}{|c|}{ Mother } & \multicolumn{3}{|c|}{ Father } & \multicolumn{3}{|c|}{ Any } \\
\hline & $(1)$ & $(2)$ & $(3)$ & $(4)$ & $(5)$ & $(6)$ & $(7)$ & $(8)$ & $(9)$ \\
\hline $\begin{array}{l}\text { Number of Hospitalizations } \\
\text { related to Mental Illness }\end{array}$ & $\begin{array}{l}0.606^{*} \\
(0.244)\end{array}$ & $\begin{array}{l}0.547^{*} \\
(0.265)\end{array}$ & $\begin{array}{l}0.527 \\
(0.306)\end{array}$ & $\begin{array}{l}0.555^{* * *} \\
(0.157)\end{array}$ & $\begin{array}{l}0.567 * * * \\
(0.167)\end{array}$ & $\begin{array}{l}0.634^{* *} \\
(0.197)\end{array}$ & $\begin{array}{l}0.558^{* * *} \\
(0.135)\end{array}$ & $\begin{array}{l}0.523^{* * *} \\
(0.155)\end{array}$ & $\begin{array}{l}0.608^{* *} \\
(0.198)\end{array}$ \\
\hline $\begin{array}{l}\text { sex } \\
(1=\text { female })\end{array}$ & & $\begin{array}{l}0.0225 \\
(0.0635)\end{array}$ & $\begin{array}{l}0.0225 \\
(0.0635)\end{array}$ & & $\begin{array}{l}0.0726 \\
(0.0612)\end{array}$ & $\begin{array}{l}0.0726 \\
(0.0612)\end{array}$ & & $\begin{array}{l}0.0493 \\
(0.0650)\end{array}$ & $\begin{array}{l}0.0489 \\
(0.0650)\end{array}$ \\
\hline $\begin{array}{l}\text { Mother's education } \\
\text { (1= above average attainment) }\end{array}$ & & $\begin{array}{l}-0.178^{* *} \\
(0.0676)\end{array}$ & & & & & & $\begin{array}{l}-0.212^{* *} \\
(0.0739)\end{array}$ & \\
\hline Mother's education * Parental Loss & & & $\begin{array}{l}0.0681 \\
(0.567)\end{array}$ & & & & & & $\begin{array}{l}0.0157 \\
(0.344)\end{array}$ \\
\hline Father repartner early & & $\begin{array}{l}0.709 \\
(0.974)\end{array}$ & $\begin{array}{l}0.708 \\
(0.976)\end{array}$ & & & & & $\begin{array}{l}0.818 \\
(0.983)\end{array}$ & $\begin{array}{l}0.824 \\
(0.983)\end{array}$ \\
\hline $\begin{array}{l}\text { Father's education } \\
(1=\text { above average attainment) }\end{array}$ & & & & & $\begin{array}{c}-0.00309 \\
(0.0677)\end{array}$ & & & $\begin{array}{l}0.0914 \\
(0.0760)\end{array}$ & \\
\hline Father's education * Parental Loss & & & & & & $\begin{array}{l}-0.252 \\
(0.363)\end{array}$ & & & $\begin{array}{l}-0.323 \\
(0.345)\end{array}$ \\
\hline Mother repartner early & & & & & $\begin{array}{l}0.339 \\
(0.960)\end{array}$ & $\begin{array}{l}0.332 \\
(0.958)\end{array}$ & & $\begin{array}{l}-0.673 \\
(0.726)\end{array}$ & $\begin{array}{l}-0.683 \\
(0.726)\end{array}$ \\
\hline Controls (Birth Year / Birth County) & No & Yes & Yes & No & Yes & Yes & No & Yes & Yes \\
\hline $\mathrm{N}$ & 70013 & 58017 & 58017 & 70013 & 62491 & 62491 & 70013 & 55532 & 55532 \\
\hline adj. R-sq & 0.000 & 0.006 & 0.006 & 0.000 & 0.005 & 0.005 & 0.000 & 0.006 & 0.006 \\
\hline
\end{tabular}


Table 7: Effect on Adult Income of Losing a Parent in Early Life, relative to losing a Parent after age 16

\begin{tabular}{|c|c|c|c|c|c|c|c|c|c|}
\hline \multirow[t]{2}{*}{ Parent Lost: } & \multicolumn{3}{|c|}{ Mother } & \multicolumn{3}{|c|}{ Father } & \multicolumn{3}{|c|}{ Any } \\
\hline & $(1)$ & $(2)$ & $(3)$ & $(4)$ & $(5)$ & $(6)$ & $(7)$ & $(8)$ & $(9)$ \\
\hline Parent lost at ages $0-1$ & $\begin{array}{c}-0.0863 \\
(0.105)\end{array}$ & $\begin{array}{l}-0.0863 \\
(0.127)\end{array}$ & $\begin{array}{l}-0.110 \\
(0.147)\end{array}$ & $\begin{array}{l}-0.194^{* *} \\
(0.0629)\end{array}$ & $\begin{array}{c}-0.233^{* *} \\
(0.0773)\end{array}$ & $\begin{array}{l}-0.201^{*} \\
(0.0862)\end{array}$ & $\begin{array}{l}-0.180^{* * *} \\
(0.0544)\end{array}$ & $\begin{array}{c}-0.190^{* *} \\
(0.0684)\end{array}$ & $\begin{array}{l}-0.175^{*} \\
(0.0826)\end{array}$ \\
\hline Parent lost at ages $2-5$ & $\begin{array}{l}-0.118^{*} \\
(0.0574)\end{array}$ & $\begin{array}{l}-0.133^{*} \\
(0.0624)\end{array}$ & $\begin{array}{l}-0.103 \\
(0.0717)\end{array}$ & $\begin{array}{c}-0.102^{* *} \\
(0.0362)\end{array}$ & $\begin{array}{l}-0.0811^{*} \\
(0.0377)\end{array}$ & $\begin{array}{l}-0.0477 \\
(0.0404)\end{array}$ & $\begin{array}{l}-0.116^{* * *} \\
(0.0308)\end{array}$ & $\begin{array}{l}-0.0944^{* *} \\
(0.0329)\end{array}$ & $\begin{array}{l}-0.0608 \\
(0.0383)\end{array}$ \\
\hline Parent lost at ages 6-10 & $\begin{array}{c}-0.132^{* *} \\
(0.0432)\end{array}$ & $\begin{array}{l}-0.126^{* *} \\
(0.0455)\end{array}$ & $\begin{array}{l}-0.130^{*} \\
(0.0526)\end{array}$ & $\begin{array}{l}-0.129^{* * *} \\
(0.0283)\end{array}$ & $\begin{array}{l}-0.116^{* * *} \\
(0.0287)\end{array}$ & $\begin{array}{l}-0.0922^{* *} \\
(0.0314)\end{array}$ & $\begin{array}{l}-0.141^{* * *} \\
(0.0240)\end{array}$ & $\begin{array}{l}-0.122^{* * *} \\
(0.0247)\end{array}$ & $\begin{array}{l}-0.111^{* * *} \\
(0.0294)\end{array}$ \\
\hline Parent lost at ages $11-15$ & $\begin{array}{c}-0.103^{* *} \\
(0.0352)\end{array}$ & $\begin{array}{l}-0.0796^{*} \\
(0.0356)\end{array}$ & $\begin{array}{l}-0.0758 \\
(0.0408)\end{array}$ & $\begin{array}{l}-0.103^{* * *} \\
(0.0238)\end{array}$ & $\begin{array}{l}-0.0761^{* *} \\
(0.0238)\end{array}$ & $\begin{array}{l}-0.0669^{*} \\
(0.0261)\end{array}$ & $\begin{array}{l}-0.116^{* * *} \\
(0.0200)\end{array}$ & $\begin{array}{l}-0.0971^{* * *} \\
(0.0204)\end{array}$ & $\begin{array}{l}-0.0737^{* *} \\
(0.0240)\end{array}$ \\
\hline $\begin{array}{l}\text { sex } \\
(1=\text { female })\end{array}$ & & $\begin{array}{l}-0.211^{* * *} \\
(0.0137)\end{array}$ & $\begin{array}{l}-0.211^{* * *} \\
(0.0137)\end{array}$ & & $\begin{array}{r}-0.197^{* * *} \\
(0.00991)\end{array}$ & $\begin{array}{l}-0.197^{* * *} \\
(0.00991)\end{array}$ & & $\begin{array}{l}-0.211^{* * *} \\
(0.00854)\end{array}$ & $\begin{array}{c}-0.211^{* * *} \\
(0.00854)\end{array}$ \\
\hline $\begin{array}{l}\text { Mother's education } \\
\text { (1= above average attainment) }\end{array}$ & & $\begin{array}{l}-0.0667^{* * *} \\
(0.0161)\end{array}$ & $\begin{array}{l}-0.0652^{* * *} \\
(0.0168)\end{array}$ & & & & & $\begin{array}{l}-0.0352^{* * *} \\
(0.0104)\end{array}$ & $\begin{array}{l}-0.0328^{* *} \\
(0.0109)\end{array}$ \\
\hline Mother's education * Parent lost at ages $0-1$ & & & $\begin{array}{l}0.0670 \\
(0.276)\end{array}$ & & & & & & $\begin{array}{r}-0.0390 \\
(0.162)\end{array}$ \\
\hline Mother's education * Parent lost at ages 2-5 & & & $\begin{array}{r}-0.0882 \\
(0.135)\end{array}$ & & & & & & $\begin{array}{l}-0.0478 \\
(0.0772)\end{array}$ \\
\hline Mother's education * Parent lost at ages $6-10$ & & & $\begin{array}{l}0.0110 \\
(0.0981)\end{array}$ & & & & & & $\begin{array}{l}0.0308 \\
(0.0586)\end{array}$ \\
\hline Mother's education * Parent lost at ages 11-15 & & & $\begin{array}{l}-0.0122 \\
(0.0803)\end{array}$ & & & & & & $\begin{array}{l}-0.0471 \\
(0.0496)\end{array}$ \\
\hline Father repartner early & & $\begin{array}{l}0.0840 \\
(0.0733)\end{array}$ & $\begin{array}{l}0.0853 \\
(0.0735)\end{array}$ & & & & & $\begin{array}{l}0.0156 \\
(0.0675)\end{array}$ & $\begin{array}{l}0.0219 \\
(0.0676)\end{array}$ \\
\hline $\begin{array}{l}\text { Father's education } \\
\text { (1= above average attainment) }\end{array}$ & & & & & $\begin{array}{l}-0.118^{* * *} \\
(0.0127)\end{array}$ & $\begin{array}{l}-0.109^{* * *} \\
(0.0133)\end{array}$ & & $\begin{array}{l}-0.100^{* * *} \\
(0.0112)\end{array}$ & $\begin{array}{l}-0.0941^{* * *} \\
(0.0118)\end{array}$ \\
\hline Father's education * Parent lost at ages $0-1$ & & & & & & $\begin{array}{l}-0.120 \\
(0.185)\end{array}$ & & & $\begin{array}{r}-0.0130 \\
(0.165)\end{array}$ \\
\hline Father's education * Parent lost at ages 2-5 & & & & & & $\begin{array}{l}-0.129 \\
(0.0960)\end{array}$ & & & $\begin{array}{l}-0.0684 \\
(0.0823)\end{array}$ \\
\hline Father's education ${ }^{*}$ Parent lost at ages $6-10$ & & & & & & $\begin{array}{l}-0.0896 \\
(0.0712)\end{array}$ & & & $\begin{array}{l}-0.0750 \\
(0.0631)\end{array}$ \\
\hline Father's education * Parent lost at ages 11-15 & & & & & & $\begin{array}{l}-0.0343 \\
(0.0585)\end{array}$ & & & $\begin{array}{l}-0.0305 \\
(0.0518)\end{array}$ \\
\hline Mother repartner early & & & & & $\begin{array}{l}-0.161 \\
(0.107)\end{array}$ & $\begin{array}{l}-0.159 \\
(0.107)\end{array}$ & & $\begin{array}{l}-0.204 \\
(0.109)\end{array}$ & $\begin{array}{l}-0.201 \\
(0.109)\end{array}$ \\
\hline Controls (Birth Year / Birth County) & No & Yes & Yes & No & Yes & Yes & No & Yes & Yes \\
\hline $\mathrm{N}$ & 118054 & 111198 & 111198 & 227922 & 220124 & 220124 & 309753 & 282830 & 282830 \\
\hline adj. R-sq & 0.000 & 0.006 & 0.006 & 0.000 & 0.006 & 0.006 & 0.000 & 0.006 & 0.006 \\
\hline
\end{tabular}


Table 8: Effect on Years of Schooling of Losing a Parent in Early Life, relative to losing a Parent after age 16

\begin{tabular}{|c|c|c|c|c|c|c|c|c|c|}
\hline \multirow[t]{2}{*}{ Parent Lost: } & \multicolumn{3}{|c|}{ Mother } & \multicolumn{3}{|c|}{ Father } & \multicolumn{3}{|c|}{ "Any } \\
\hline & $(1)$ & $(2)$ & $(3)$ & $(4)$ & $(5)$ & $(6)$ & $(7)$ & $(8)$ & $(9)$ \\
\hline Parent lost at ages $0-1$ & $\begin{array}{l}0.0219 \\
(0.0711)\end{array}$ & $\begin{array}{l}-0.0532 \\
(0.0861)\end{array}$ & $\begin{array}{l}0.0294 \\
(0.104)\end{array}$ & $\begin{array}{l}-0.0247 \\
(0.0398)\end{array}$ & $\begin{array}{l}-0.0423 \\
(0.0464)\end{array}$ & $\begin{array}{l}0.0221 \\
(0.0526)\end{array}$ & $\begin{array}{l}-0.0444 \\
(0.0348)\end{array}$ & $\begin{array}{l}-0.0461 \\
(0.0423)\end{array}$ & $\begin{array}{l}-0.0272 \\
(0.0532)\end{array}$ \\
\hline Parent lost at ages $2-5$ & $\begin{array}{l}-0.0550 \\
(0.0376)\end{array}$ & $\begin{array}{l}-0.168^{* * *} \\
(0.0398)\end{array}$ & $\begin{array}{l}-0.160^{* * *} \\
(0.0466)\end{array}$ & $\begin{array}{l}-0.112^{* * *} \\
(0.0238)\end{array}$ & $\begin{array}{l}-0.122^{* * *} \\
(0.0244)\end{array}$ & $\begin{array}{l}-0.0512 \\
(0.0277)\end{array}$ & $\begin{array}{l}-0.127^{* * *} \\
(0.0202)\end{array}$ & $\begin{array}{l}-0.131^{* * *} \\
(0.0214)\end{array}$ & $\begin{array}{l}-0.0751^{* *} \\
(0.0262)\end{array}$ \\
\hline Parent lost at ages $6-10$ & $\begin{array}{c}-0.0563^{*} \\
(0.0275)\end{array}$ & $\begin{array}{l}-0.148^{* * *} \\
(0.0285)\end{array}$ & $\begin{array}{c}-0.0777^{*} \\
(0.0331)\end{array}$ & $\begin{array}{l}-0.106^{* * *} \\
(0.0183)\end{array}$ & $\begin{array}{l}-0.112^{* * *} \\
(0.0182)\end{array}$ & $\begin{array}{l}-0.0975^{* * *} \\
(0.0209)\end{array}$ & $\begin{array}{l}-0.122^{* * *} \\
(0.0154)\end{array}$ & $\begin{array}{l}-0.133^{* * *} \\
(0.0156)\end{array}$ & $\begin{array}{l}-0.111^{* * *} \\
(0.0192)\end{array}$ \\
\hline Parent lost at ages $11-15$ & $\begin{array}{l}-0.0339 \\
(0.0231)\end{array}$ & $\begin{array}{l}-0.0765^{* * *} \\
(0.0232)\end{array}$ & $\begin{array}{l}-0.0394 \\
(0.0275)\end{array}$ & $\begin{array}{l}-0.0961^{* * *} \\
(0.0156)\end{array}$ & $\begin{array}{l}-0.109^{* * *} \\
(0.0155)\end{array}$ & $\begin{array}{l}-0.0788^{* * *} \\
(0.0178)\end{array}$ & $\begin{array}{l}-0.108^{* * *} \\
(0.0131)\end{array}$ & $\begin{array}{l}-0.117^{* * *} \\
(0.0132)\end{array}$ & $\begin{array}{l}-0.0888^{* * *} \\
(0.0164)\end{array}$ \\
\hline $\operatorname{sex}(1=$ female $)$ & & $\begin{array}{l}0.431^{* * *} \\
(0.00952)\end{array}$ & $\begin{array}{l}0.431^{* * *} \\
(0.00952)\end{array}$ & & $\begin{array}{l}0.469^{* * *} \\
(0.00682)\end{array}$ & $\begin{array}{l}0.469^{* * *} \\
(0.00682)\end{array}$ & & $\begin{array}{l}0.452^{* * *} \\
(0.00589)\end{array}$ & $\begin{array}{l}0.452^{* * *} \\
(0.00589)\end{array}$ \\
\hline $\begin{array}{l}\text { Mother's education } \\
\text { (1= above average attainment) }\end{array}$ & & $\begin{array}{l}0.923^{* * *} \\
(0.0107)\end{array}$ & $\begin{array}{l}0.938^{* * *} \\
(0.0113)\end{array}$ & & & & & $\begin{array}{l}0.689^{* * *} \\
(0.00706)\end{array}$ & $\begin{array}{l}0.689^{* * *} \\
(0.00750)\end{array}$ \\
\hline Mother's education * Parent lost at ages $0-1$ & & & $\begin{array}{l}-0.241 \\
(0.182)\end{array}$ & & & & & & $\begin{array}{l}0.0647 \\
(0.0982)\end{array}$ \\
\hline Mother's education * Parent lost at ages 2-5 & & & $\begin{array}{l}-0.0359 \\
(0.0825)\end{array}$ & & & & & & $\begin{array}{l}0.0221 \\
(0.0499)\end{array}$ \\
\hline Mother's education * Parent lost at ages $6-10$ & & & $\begin{array}{l}-0.223^{* * *} \\
(0.0609)\end{array}$ & & & & & & $\begin{array}{l}-0.00900 \\
(0.0369)\end{array}$ \\
\hline Mother's education ${ }^{*}$ Parent lost at ages 11-15 & & & $\begin{array}{l}-0.116^{*} \\
(0.0504)\end{array}$ & & & & & & $\begin{array}{l}-0.0152 \\
(0.0316)\end{array}$ \\
\hline Father repartner early & & $\begin{array}{l}0.231^{* * *} \\
(0.0487)\end{array}$ & $\begin{array}{l}0.246^{* * *} \\
(0.0489)\end{array}$ & & & & & $\begin{array}{l}0.129^{* *} \\
(0.0415)\end{array}$ & $\begin{array}{l}0.143^{* * *} \\
(0.0416)\end{array}$ \\
\hline $\begin{array}{l}\text { Father's education } \\
\text { (1= above average attainment) }\end{array}$ & & & & & $\begin{array}{l}0.849^{* * *} \\
(0.00809)\end{array}$ & $\begin{array}{l}0.864^{* * *} \\
(0.00858)\end{array}$ & & $\begin{array}{l}0.611^{* * *} \\
(0.00742)\end{array}$ & $\begin{array}{l}0.624^{* * *} \\
(0.00788)\end{array}$ \\
\hline Father's education * Parent lost at ages $0-1$ & & & & & & $\begin{array}{l}-0.231^{*} \\
(0.108)\end{array}$ & & & $\begin{array}{l}-0.135 \\
(0.102)\end{array}$ \\
\hline Father's education * Parent lost at ages 2-5 & & & & & & $\begin{array}{l}-0.270^{* * *} \\
(0.0571)\end{array}$ & & & $\begin{array}{l}-0.227^{* * *} \\
(0.0518)\end{array}$ \\
\hline Father's education ${ }^{*}$ Parent lost at ages $6-10$ & & & & & & $\begin{array}{l}-0.0540 \\
(0.0420)\end{array}$ & & & $\begin{array}{l}-0.0727 \\
(0.0383)\end{array}$ \\
\hline Father's education * Parent lost at ages 11-15 & & & & & & $\begin{array}{c}-0.110^{* *} \\
(0.0359)\end{array}$ & & & $\begin{array}{c}-0.0833^{*} \\
(0.0326)\end{array}$ \\
\hline Mother repartner early & & & & & $\begin{array}{l}0.00632 \\
(0.0619)\end{array}$ & $\begin{array}{l}0.00961 \\
(0.0619)\end{array}$ & & $\begin{array}{l}-0.00671 \\
(0.0610)\end{array}$ & $\begin{array}{l}-0.00438 \\
(0.0609)\end{array}$ \\
\hline Controls (Birth Year / Birth County) & No & Yes & Yes & No & Yes & Yes & No & Yes & Yes \\
\hline $\mathrm{N}$ & 120489 & 113468 & 113468 & 232790 & 224731 & 224731 & 316385 & 288651 & 288651 \\
\hline adj. R-sq & 0.000 & 0.088 & 0.088 & 0.000 & 0.073 & 0.073 & 0.000 & 0.110 & 0.110 \\
\hline
\end{tabular}


Table 9: Effect on Adult Hospitalizations of Losing a Parent in Early Life, relative to losing a Parent after age 16

\begin{tabular}{|c|c|c|c|c|c|c|c|c|c|}
\hline \multirow{2}{*}{ Parent Lost: } & \multicolumn{3}{|c|}{ Mother } & \multicolumn{3}{|c|}{ Father } & \multicolumn{3}{|c|}{ "Any } \\
\hline & $(1)$ & $(2)$ & $(3)$ & $(4)$ & $(5)$ & $(6)$ & $(7)$ & $(8)$ & $(9)$ \\
\hline Parent lost at ages $0-1$ & $\begin{array}{c}-0.0258 \\
(0.343)\end{array}$ & $\begin{array}{l}0.325 \\
(0.474)\end{array}$ & $\begin{array}{l}0.306 \\
(0.645)\end{array}$ & $\begin{array}{l}0.211 \\
(0.141)\end{array}$ & $\begin{array}{l}0.367^{*} \\
(0.157)\end{array}$ & $\begin{array}{l}0.224 \\
(0.177)\end{array}$ & $\begin{array}{l}0.201 \\
(0.134)\end{array}$ & $\begin{array}{l}0.328^{*} \\
(0.161)\end{array}$ & $\begin{array}{l}0.144 \\
(0.207)\end{array}$ \\
\hline Parent lost at ages 2-5 & $\begin{array}{l}0.373^{*} \\
(0.181)\end{array}$ & $\begin{array}{l}0.537^{* *} \\
(0.208)\end{array}$ & $\begin{array}{l}0.516^{*} \\
(0.260)\end{array}$ & $\begin{array}{l}0.373^{* * *} \\
(0.0994)\end{array}$ & $\begin{array}{l}0.406^{* * *} \\
(0.103)\end{array}$ & $\begin{array}{l}0.382^{* *} \\
(0.121)\end{array}$ & $\begin{array}{l}0.425^{* * *} \\
(0.0882)\end{array}$ & $\begin{array}{l}0.443^{* * *} \\
(0.0962)\end{array}$ & $\begin{array}{l}0.452^{* * *} \\
(0.124)\end{array}$ \\
\hline Parent lost at ages 6-10 & $\begin{array}{c}-0.0447 \\
(0.112)\end{array}$ & $\begin{array}{l}-0.00251 \\
(0.109)\end{array}$ & $\begin{array}{l}0.00409 \\
(0.136)\end{array}$ & $\begin{array}{l}0.288^{* * *} \\
(0.0769)\end{array}$ & $\begin{array}{l}0.323^{* * *} \\
(0.0800)\end{array}$ & $\begin{array}{l}0.398^{* * *} \\
(0.100)\end{array}$ & $\begin{array}{l}0.235^{* * *} \\
(0.0642)\end{array}$ & $\begin{array}{l}0.267^{* * *} \\
(0.0675)\end{array}$ & $\begin{array}{l}0.341^{* * *} \\
(0.0913)\end{array}$ \\
\hline Parent lost at ages $11-15$ & $\begin{array}{l}-0.107 \\
(0.0838)\end{array}$ & $\begin{array}{l}0.00518 \\
(0.0874)\end{array}$ & $\begin{array}{l}0.0428 \\
(0.106)\end{array}$ & $\begin{array}{l}0.0931 \\
(0.0644)\end{array}$ & $\begin{array}{l}0.121 \\
(0.0655)\end{array}$ & $\begin{array}{l}0.138 \\
(0.0787)\end{array}$ & $\begin{array}{l}0.0752 \\
(0.0521)\end{array}$ & $\begin{array}{l}0.139^{*} \\
(0.0553)\end{array}$ & $\begin{array}{l}0.187^{*} \\
(0.0749)\end{array}$ \\
\hline $\operatorname{sex}(1=$ female $)$ & & $\begin{array}{l}1.023^{* * *} \\
(0.0452)\end{array}$ & $\begin{array}{l}1.023^{* * *} \\
(0.0452)\end{array}$ & & $\begin{array}{l}1.029^{* * *} \\
(0.0300)\end{array}$ & $\begin{array}{l}1.030^{* * *} \\
(0.0300)\end{array}$ & & $\begin{array}{l}1.057^{* * *} \\
(0.0260)\end{array}$ & $\begin{array}{l}1.057^{* * *} \\
(0.0260)\end{array}$ \\
\hline $\begin{array}{l}\text { Mother's education } \\
\text { (1= above average attainment) }\end{array}$ & & $\begin{array}{l}-0.531^{* * *} \\
(0.0448)\end{array}$ & $\begin{array}{l}-0.526^{* * *} \\
(0.0475)\end{array}$ & & & & & $\begin{array}{l}-0.377^{* * *} \\
(0.0274)\end{array}$ & $\begin{array}{l}-0.367^{* * *} \\
(0.0292)\end{array}$ \\
\hline Mother's education * Parent lost at ages 0-1 & & & $\begin{array}{l}0.0549 \\
(0.841)\end{array}$ & & & & & & $\begin{array}{l}0.370 \\
(0.369)\end{array}$ \\
\hline Mother's education * Parent lost at ages 2-5 & & & $\begin{array}{l}0.0615 \\
(0.392)\end{array}$ & & & & & & $\begin{array}{l}-0.0712 \\
(0.221)\end{array}$ \\
\hline Mother's education * Parent lost at ages 6-10 & & & $\begin{array}{l}-0.0221 \\
(0.200)\end{array}$ & & & & & & $\begin{array}{l}-0.0809 \\
(0.142)\end{array}$ \\
\hline Mother's education * Parent lost at ages 11-15 & & & $\begin{array}{l}-0.123 \\
(0.183)\end{array}$ & & & & & & $\begin{array}{l}-0.141 \\
(0.111)\end{array}$ \\
\hline Father repartner early & & $\begin{array}{l}-0.210 \\
(0.245)\end{array}$ & $\begin{array}{l}-0.209 \\
(0.246)\end{array}$ & & & & & $\begin{array}{l}-0.172 \\
(0.193)\end{array}$ & $\begin{array}{l}-0.169 \\
(0.194)\end{array}$ \\
\hline $\begin{array}{l}\text { Father's education } \\
\text { (1= above average attainment) }\end{array}$ & & & & & $\begin{array}{l}-0.370^{* * *} \\
(0.0315)\end{array}$ & $\begin{array}{l}-0.361^{* * *} \\
(0.0335)\end{array}$ & & $\begin{array}{l}-0.241^{* * *} \\
(0.0289)\end{array}$ & $\begin{array}{l}-0.235^{* * *} \\
(0.0309)\end{array}$ \\
\hline Father's education * Parent lost at ages $0-1$ & & & & & & $\begin{array}{l}0.574 \\
(0.373)\end{array}$ & & & $\begin{array}{l}0.266 \\
(0.357)\end{array}$ \\
\hline Father's education * Parent lost at ages 2-5 & & & & & & $\begin{array}{l}0.0961 \\
(0.227)\end{array}$ & & & $\begin{array}{l}0.0447 \\
(0.228)\end{array}$ \\
\hline Father's education ${ }^{*}$ Parent lost at ages 6-10 & & & & & & $\begin{array}{l}-0.283 \\
(0.153)\end{array}$ & & & $\begin{array}{l}-0.184 \\
(0.136)\end{array}$ \\
\hline Father's education * Parent lost at ages 11-15 & & & & & & $\begin{array}{l}-0.0667 \\
(0.138)\end{array}$ & & & $\begin{array}{l}-0.0196 \\
(0.118)\end{array}$ \\
\hline Mother repartner early & & & & & $\begin{array}{l}0.103 \\
(0.229)\end{array}$ & $\begin{array}{l}0.102 \\
(0.228)\end{array}$ & & $\begin{array}{c}-0.182 \\
(0.163)\end{array}$ & $\begin{array}{l}-0.178 \\
(0.164)\end{array}$ \\
\hline Controls (Birth Year / Birth County) & No & Yes & Yes & No & Yes & Yes & No & Yes & Yes \\
\hline $\mathrm{N}$ & 82832 & 77840 & 77840 & 160058 & 154424 & 154424 & 216971 & 197518 & 197518 \\
\hline adj. R-sq & 0.000 & 0.010 & 0.010 & 0.000 & 0.010 & 0.010 & 0.000 & 0.012 & 0.012 \\
\hline
\end{tabular}


Table 10: Effect on Days of Hospitalization of Losing a Parent in Early Life, relative to losing a Parent after age 16

\begin{tabular}{|c|c|c|c|c|c|c|c|c|c|}
\hline \multirow[t]{2}{*}{ Parent Lost: } & \multicolumn{3}{|c|}{ Mother } & \multicolumn{3}{|c|}{ Father } & \multicolumn{3}{|c|}{ Any } \\
\hline & $(1)$ & $(2)$ & $(3)$ & $(4)$ & $(5)$ & $(6)$ & $(7)$ & $(8)$ & $(9)$ \\
\hline Parent lost at ages $0-1$ & $\begin{array}{l}3.790 \\
(7.333)\end{array}$ & $\begin{array}{l}9.580 \\
(10.74)\end{array}$ & $\begin{array}{l}10.75 \\
(15.42)\end{array}$ & $\begin{array}{l}4.843 \\
(3.424)\end{array}$ & $\begin{array}{l}6.528 \\
(4.175)\end{array}$ & $\begin{array}{l}4.656 \\
(5.125)\end{array}$ & $\begin{array}{l}4.587 \\
(3.120)\end{array}$ & $\begin{array}{l}6.228 \\
(4.247)\end{array}$ & $\begin{array}{l}5.357 \\
(6.364)\end{array}$ \\
\hline Parent lost at ages $2-5$ & $\begin{array}{l}10.67^{* *} \\
(3.595)\end{array}$ & $\begin{array}{l}11.74^{* *} \\
(4.271)\end{array}$ & $\begin{array}{l}11.04^{*} \\
(5.494)\end{array}$ & $\begin{array}{l}6.742^{* * * *} \\
(2.042)\end{array}$ & $\begin{array}{l}7.625^{* * *} \\
(2.205)\end{array}$ & $\begin{array}{l}8.126^{* *} \\
(2.597)\end{array}$ & $\begin{array}{l}8.142^{* * * *} \\
(1.783)\end{array}$ & $\begin{array}{l}8.740^{* * *} \\
(2.026)\end{array}$ & $\begin{array}{l}8.816^{* * *} \\
(2.555)\end{array}$ \\
\hline Parent lost at ages $6-10$ & $\begin{array}{l}4.043 \\
(2.524)\end{array}$ & $\begin{array}{l}3.800 \\
(2.815)\end{array}$ & $\begin{array}{l}2.470 \\
(3.125)\end{array}$ & $\begin{array}{l}5.606^{* *} \\
(1.909)\end{array}$ & $\begin{array}{l}5.766^{* *} \\
(1.967)\end{array}$ & $\begin{array}{l}6.385^{* *} \\
(2.227)\end{array}$ & $\begin{array}{l}5.206^{* * *} \\
(1.521)\end{array}$ & $\begin{array}{l}4.586^{* *} \\
(1.568)\end{array}$ & $\begin{array}{l}4.634^{*} \\
(1.900)\end{array}$ \\
\hline Parent lost at ages $11-15$ & $\begin{array}{l}-1.793 \\
(9.021)\end{array}$ & $\begin{array}{l}-2.033 \\
(10.10)\end{array}$ & $\begin{array}{l}-5.428 \\
(14.21)\end{array}$ & $\begin{array}{l}1.191 \\
(3.888)\end{array}$ & $\begin{array}{l}1.218 \\
(4.062)\end{array}$ & $\begin{array}{l}0.617 \\
(5.404)\end{array}$ & $\begin{array}{l}0.0179 \\
(3.940)\end{array}$ & $\begin{array}{l}-0.349 \\
(4.467)\end{array}$ & $\begin{array}{l}-1.972 \\
(6.968)\end{array}$ \\
\hline $\operatorname{sex}(1=$ female $)$ & & $\begin{array}{l}-0.260 \\
(3.063)\end{array}$ & $\begin{array}{l}-0.251 \\
(3.067)\end{array}$ & & $\begin{array}{l}-5.895^{* * *} \\
(1.489)\end{array}$ & $\begin{array}{l}-5.890^{* * *} \\
(1.488)\end{array}$ & & $\begin{array}{l}-3.517^{*} \\
(1.455)\end{array}$ & $\begin{array}{c}-3.513^{*} \\
(1.456)\end{array}$ \\
\hline $\begin{array}{l}\text { Mother's education } \\
\text { (1= above average attainment) }\end{array}$ & & $\begin{array}{l}-6.799 \\
(4.215)\end{array}$ & $\begin{array}{l}-7.505 \\
(4.612)\end{array}$ & & & & & $\begin{array}{l}-1.875 \\
(1.368)\end{array}$ & $\begin{array}{l}-2.074 \\
(1.508)\end{array}$ \\
\hline Mother's education * Parent lost at ages 0-1 & & & $\begin{array}{l}-3.140 \\
(17.26)\end{array}$ & & & & & & $\begin{array}{l}-1.302 \\
(7.078)\end{array}$ \\
\hline Mother's education * Parent lost at ages 2-5 & & & $\begin{array}{l}2.468 \\
(7.877)\end{array}$ & & & & & & $\begin{array}{l}-0.347 \\
(4.383)\end{array}$ \\
\hline Mother's education ${ }^{*}$ Parent lost at ages $6-10$ & & & $\begin{array}{l}4.456 \\
(6.421)\end{array}$ & & & & & & $\begin{array}{l}1.990 \\
(3.410)\end{array}$ \\
\hline Mother's education * Parent lost at ages 11-15 & & & $\begin{array}{l}11.17 \\
(14.60)\end{array}$ & & & & & & $\begin{array}{l}2.538 \\
(5.258)\end{array}$ \\
\hline Father repartner early & & $\begin{array}{l}-1.106 \\
(5.839)\end{array}$ & $\begin{array}{l}-1.460 \\
(5.803)\end{array}$ & & & & & $\begin{array}{l}-0.443 \\
(4.245)\end{array}$ & $\begin{array}{l}-0.566 \\
(4.254)\end{array}$ \\
\hline $\begin{array}{l}\text { Father's education } \\
(1=\text { above average attainment })\end{array}$ & & & & & $\begin{array}{l}-1.989 \\
(2.357)\end{array}$ & $\begin{array}{l}-2.027 \\
(2.611)\end{array}$ & & $\begin{array}{l}-1.428 \\
(1.775)\end{array}$ & $\begin{array}{l}-1.540 \\
(1.971)\end{array}$ \\
\hline Father's education * Parent lost at ages $0-1$ & & & & & & $\begin{array}{l}7.535 \\
(9.554)\end{array}$ & & & $\begin{array}{l}4.716 \\
(8.216)\end{array}$ \\
\hline Father's education * Parent lost at ages 2-5 & & & & & & $\begin{array}{l}-1.985 \\
(4.990)\end{array}$ & & & $\begin{array}{l}0.130 \\
(4.700)\end{array}$ \\
\hline Father's education ${ }^{*}$ Parent lost at ages $6-10$ & & & & & & $\begin{array}{l}-2.337 \\
(4.824)\end{array}$ & & & $\begin{array}{l}-2.330 \\
(3.499)\end{array}$ \\
\hline Father's education * Parent lost at ages 11-15 & & & & & & $\begin{array}{l}2.315 \\
(6.168)\end{array}$ & & & $\begin{array}{l}3.140 \\
(5.006)\end{array}$ \\
\hline Mother repartner early & & & & & $\begin{array}{l}3.702 \\
(7.131)\end{array}$ & $\begin{array}{l}3.633 \\
(7.152)\end{array}$ & & $\begin{array}{l}5.525 \\
(7.825)\end{array}$ & $\begin{array}{l}5.510 \\
(7.822)\end{array}$ \\
\hline Controls (Birth Year / Birth County) & No & Yes & Yes & No & Yes & Yes & No & Yes & Yes \\
\hline $\mathrm{N}$ & 82832 & 77840 & 77840 & 160058 & 154424 & 154424 & 216971 & 197518 & 197518 \\
\hline adj. R-sq & 0.000 & 0.002 & 0.002 & 0.000 & 0.002 & 0.002 & 0.000 & 0.002 & 0.002 \\
\hline
\end{tabular}


Table 11: Effect on Mental Health Hospitalizations of Losing a Parent in Early Life, relative to losing a Parent after age 16

\begin{tabular}{|c|c|c|c|c|c|c|c|c|c|}
\hline \multirow[t]{2}{*}{ Parent Lost: } & \multicolumn{3}{|c|}{ Mother } & \multicolumn{3}{|c|}{ Father } & \multicolumn{3}{|c|}{ Any } \\
\hline & $(1)$ & $(2)$ & $(3)$ & $(4)$ & $(5)$ & $(6)$ & $(7)$ & $(8)$ & $(9)$ \\
\hline Parent lost at ages $0-1$ & $\begin{array}{l}-0.580 \\
(1.061)\end{array}$ & $\begin{array}{l}0.117 \\
(1.457)\end{array}$ & $\begin{array}{l}1.089 \\
(2.067)\end{array}$ & $\begin{array}{c}-0.292 \\
(0.501)\end{array}$ & $\begin{array}{c}-0.110 \\
(0.483)\end{array}$ & $\begin{array}{l}-0.382 \\
(0.558)\end{array}$ & $\begin{array}{l}-0.301 \\
(0.462)\end{array}$ & $\begin{array}{l}0.0712 \\
(0.551)\end{array}$ & $\begin{array}{c}-0.467 \\
(0.762)\end{array}$ \\
\hline Parent lost at ages $2-5$ & $\begin{array}{l}1.088 \\
(0.765)\end{array}$ & $\begin{array}{l}1.161 \\
(0.881)\end{array}$ & $\begin{array}{l}1.644 \\
(1.106)\end{array}$ & $\begin{array}{l}0.204 \\
(0.320)\end{array}$ & $\begin{array}{l}0.312 \\
(0.322)\end{array}$ & $\begin{array}{l}0.342 \\
(0.344)\end{array}$ & $\begin{array}{l}0.514 \\
(0.319)\end{array}$ & $\begin{array}{l}0.595 \\
(0.361)\end{array}$ & $\begin{array}{c}0.892^{*} \\
(0.437)\end{array}$ \\
\hline Parent lost at ages $6-10$ & $\begin{array}{c}-0.333 \\
(0.423)\end{array}$ & $\begin{array}{l}-0.640 \\
(0.407)\end{array}$ & $\begin{array}{l}-0.640 \\
(0.470)\end{array}$ & $\begin{array}{l}0.413 \\
(0.341)\end{array}$ & $\begin{array}{l}0.762^{*} \\
(0.374)\end{array}$ & $\begin{array}{l}1.201^{*} \\
(0.474)\end{array}$ & $\begin{array}{l}0.240 \\
(0.276)\end{array}$ & $\begin{array}{l}0.526 \\
(0.321)\end{array}$ & $\begin{array}{c}0.984^{*} \\
(0.445)\end{array}$ \\
\hline Parent lost at ages $11-15$ & $\begin{array}{c}-0.461 \\
(0.318)\end{array}$ & $\begin{array}{l}-0.211 \\
(0.357)\end{array}$ & $\begin{array}{c}-0.271 \\
(0.383)\end{array}$ & $\begin{array}{c}-0.0501 \\
(0.221)\end{array}$ & $\begin{array}{c}-0.0664 \\
(0.226)\end{array}$ & $\begin{array}{l}-0.111 \\
(0.245)\end{array}$ & $\begin{array}{l}-0.142 \\
(0.185)\end{array}$ & $\begin{array}{c}-0.0907 \\
(0.200)\end{array}$ & $\begin{array}{c}-0.162 \\
(0.234)\end{array}$ \\
\hline $\operatorname{sex}(1=$ female $)$ & & $\begin{array}{c}-0.249 \\
(0.183)\end{array}$ & $\begin{array}{l}-0.249 \\
(0.183)\end{array}$ & & $\begin{array}{c}-0.198 \\
(0.130)\end{array}$ & $\begin{array}{c}-0.203 \\
(0.130)\end{array}$ & & $\begin{array}{l}-0.168 \\
(0.117)\end{array}$ & $\begin{array}{c}-0.170 \\
(0.117)\end{array}$ \\
\hline $\begin{array}{l}\text { Mother's education } \\
\text { (1= above average attainment) }\end{array}$ & & $\begin{array}{l}0.0249 \\
(0.221)\end{array}$ & $\begin{array}{l}0.0669 \\
(0.239)\end{array}$ & & & & & $\begin{array}{l}-0.189 \\
(0.140)\end{array}$ & $\begin{array}{l}-0.186 \\
(0.153)\end{array}$ \\
\hline Mother's education * Parent lost at ages 0-1 & & & $\begin{array}{l}-3.069 \\
(2.198)\end{array}$ & & & & & & $\begin{array}{l}1.588 \\
(1.147)\end{array}$ \\
\hline Mother's education * Parent lost at ages 2-5 & & & $\begin{array}{l}-1.393 \\
(1.733)\end{array}$ & & & & & & $\begin{array}{l}-0.507 \\
(0.913)\end{array}$ \\
\hline Mother's education * Parent lost at ages 6-10 & & & $\begin{array}{l}0.000863 \\
(0.772)\end{array}$ & & & & & & $\begin{array}{l}-0.508 \\
(0.592)\end{array}$ \\
\hline Mother's education * Parent lost at ages 11-15 & & & $\begin{array}{l}0.208 \\
(0.868)\end{array}$ & & & & & & $\begin{array}{l}0.314 \\
(0.502)\end{array}$ \\
\hline Father repartner early & & $\begin{array}{l}1.101 \\
(1.417)\end{array}$ & $\begin{array}{l}1.088 \\
(1.425)\end{array}$ & & & & & $\begin{array}{l}0.888 \\
(1.185)\end{array}$ & $\begin{array}{l}0.908 \\
(1.188)\end{array}$ \\
\hline $\begin{array}{l}\text { Father's education } \\
\text { (1= above average attainment) }\end{array}$ & & & & & $\begin{array}{l}0.0445 \\
(0.153)\end{array}$ & $\begin{array}{l}0.113 \\
(0.167)\end{array}$ & & $\begin{array}{l}0.146 \\
(0.144)\end{array}$ & $\begin{array}{l}0.225 \\
(0.158)\end{array}$ \\
\hline Father's education * Parent lost at ages 0-1 & & & & & & $\begin{array}{l}1.018 \\
(1.094)\end{array}$ & & & $\begin{array}{l}0.306 \\
(1.009)\end{array}$ \\
\hline Father's education * Parent lost at ages 2-5 & & & & & & $\begin{array}{l}-0.116 \\
(0.807)\end{array}$ & & & $\begin{array}{l}-0.566 \\
(0.899)\end{array}$ \\
\hline Father's education * Parent lost at ages 6-10 & & & & & & $\begin{array}{l}-1.688^{*} \\
(0.660)\end{array}$ & & & $\begin{array}{c}-1.167^{*} \\
(0.575)\end{array}$ \\
\hline Father's education * Parent lost at ages 11-15 & & & & & & $\begin{array}{l}0.173 \\
(0.587)\end{array}$ & & & $\begin{array}{c}-0.0524 \\
(0.520)\end{array}$ \\
\hline Mother repartner early & & & & & $\begin{array}{l}-0.181 \\
(1.085)\end{array}$ & $\begin{array}{l}-0.159 \\
(1.080)\end{array}$ & & $\begin{array}{c}-1.303^{*} \\
(0.634)\end{array}$ & $\begin{array}{r}-1.275^{*} \\
(0.633)\end{array}$ \\
\hline Controls (Birth Year / Birth County) & No & Yes & Yes & No & Yes & Yes & No & Yes & Yes \\
\hline $\begin{array}{l}\mathrm{N} \\
\text { adj. R-sq }\end{array}$ & $\begin{array}{l}9082 \\
0.000\end{array}$ & $\begin{array}{l}8256 \\
0.006\end{array}$ & $\begin{array}{l}8256 \\
0.006\end{array}$ & $\begin{array}{l}16238 \\
0.000\end{array}$ & $\begin{array}{l}15289 \\
0.006\end{array}$ & $\begin{array}{l}15289 \\
0.006\end{array}$ & $\begin{array}{l}21976 \\
0.000\end{array}$ & $\begin{array}{l}18813 \\
0.006\end{array}$ & $\begin{array}{l}18813 \\
0.006\end{array}$ \\
\hline
\end{tabular}

Note: Heteroskedasticity-robust standard errors in parentheses. Where indicated, the models control for the individual's sex, birth year, birth county, the Note: Heteroskedasticity-robust standard errors in parentheses. Where indicated, the models control for the individual's sex, birth year, birth county, the
level of education of the lost parent, and for the repartnering behavior of the surviving parent. Early loss of a parent is interacted, where indicated, with the education of the lost parent. Inclusion in the model is conditional on observing a parental death.

${ }^{*} \mathrm{p}<0.05,{ }^{* *} \mathrm{p}<0.01,{ }^{* * *} \mathrm{p}<0.001$ 
Table 12: Effect on Adult Income of Losing a Parent in Early Life, relative to losing a Parent after age 16: Sibling-Approach

\begin{tabular}{|c|c|c|c|c|c|c|}
\hline \multirow[t]{2}{*}{ Parent Lost: } & \multicolumn{2}{|c|}{ Mother } & \multicolumn{2}{|c|}{ Father } & \multicolumn{2}{|c|}{ Any } \\
\hline & (1) & $(2)$ & $(3)$ & $(4)$ & $(5)$ & $(6)$ \\
\hline Parent Lost at Ages 0-1 & $\begin{array}{l}-0.00660 \\
(0.326)\end{array}$ & $\begin{array}{c}-0.0435 \\
(0.333)\end{array}$ & $\begin{array}{l}0.0106 \\
(0.169)\end{array}$ & $\begin{array}{l}0.0482 \\
(0.171)\end{array}$ & $\begin{array}{l}0.00975 \\
(0.146)\end{array}$ & $\begin{array}{l}0.0169 \\
(0.148)\end{array}$ \\
\hline Parent Lost at Ages 2-5 & $\begin{array}{l}-0.0237 \\
(0.177)\end{array}$ & $\begin{array}{r}-0.0572 \\
(0.185)\end{array}$ & $\begin{array}{l}0.0401 \\
(0.113)\end{array}$ & $\begin{array}{l}0.0834 \\
(0.115)\end{array}$ & $\begin{array}{l}0.0327 \\
(0.0921)\end{array}$ & $\begin{array}{l}0.0499 \\
(0.0946)\end{array}$ \\
\hline Parent Lost at Ages 6-10 & $\begin{array}{l}-0.107 \\
(0.120)\end{array}$ & $\begin{array}{l}-0.124 \\
(0.125)\end{array}$ & $\begin{array}{l}-0.0491 \\
(0.0795)\end{array}$ & $\begin{array}{l}-0.0226 \\
(0.0816)\end{array}$ & $\begin{array}{l}-0.0673 \\
(0.0649)\end{array}$ & $\begin{array}{c}-0.0573 \\
(0.0669)\end{array}$ \\
\hline Parent Lost at Ages 11-15 & $\begin{array}{l}0.0393 \\
(0.0833)\end{array}$ & $\begin{array}{l}0.0346 \\
(0.0851)\end{array}$ & $\begin{array}{l}-0.0654 \\
(0.0574)\end{array}$ & $\begin{array}{l}-0.0517 \\
(0.0584)\end{array}$ & $\begin{array}{l}-0.0341 \\
(0.0472)\end{array}$ & $\begin{array}{l}-0.0279 \\
(0.0482)\end{array}$ \\
\hline $\operatorname{sex}(1=$ female $)$ & & $\begin{array}{l}-0.188^{* * *} \\
(0.0238)\end{array}$ & & $\begin{array}{l}-0.210^{* * *} \\
(0.0179)\end{array}$ & & $\begin{array}{c}-0.205^{* * *} \\
(0.0150)\end{array}$ \\
\hline Controls (Birth Year / Birth County) & No & Yes & No & Yes & No & Yes \\
\hline $\begin{array}{l}\mathrm{N} \\
\text { adj. R-sq }\end{array}$ & $\begin{array}{l}118054 \\
0.000\end{array}$ & $\begin{array}{l}118054 \\
0.003\end{array}$ & $\begin{array}{l}227922 \\
0.000\end{array}$ & $\begin{array}{l}227922 \\
0.003 \\
\end{array}$ & $\begin{array}{l}309753 \\
0.000\end{array}$ & $\begin{array}{l}309753 \\
0.003 \\
\end{array}$ \\
\hline \multicolumn{7}{|c|}{$\begin{array}{l}\text { Source: Authors' calculations with data from Statistics Sweden (SCB) } \\
\text { Note: Heteroskedasticity-robust standard errors in parentheses. Where indicated, the models control for the individual's } \\
\text { sex, birth year, and birth county. Inclusion in the model is conditional on observing a parental death, and on having a } \\
\text { sibling (same mother ID) on a different age-category. } \\
{ }^{*} \mathrm{p}<0.05,{ }^{* *} \mathrm{p}<0.01,{ }^{* * *} \mathrm{p}<0.001\end{array}$} \\
\hline \multicolumn{7}{|c|}{$\begin{array}{l}\text { Table 13: Effect on Years of Schooling of Losing a Parent in Early Life, relative to losing a Parent } \\
\text { after age 16: Sibling-Approach }\end{array}$} \\
\hline \multirow[t]{2}{*}{ Parent Lost: } & \multicolumn{2}{|c|}{ Mother } & \multicolumn{2}{|c|}{ Father } & \multicolumn{2}{|c|}{ Any } \\
\hline & $(1)$ & $(2)$ & $(3)$ & $(4)$ & $(5)$ & $(6)$ \\
\hline Parent Lost at Ages 0-1 & $\begin{array}{l}-0.206 \\
(0.169)\end{array}$ & $\begin{array}{l}-0.182 \\
(0.170)\end{array}$ & $\begin{array}{l}0.138 \\
(0.0856)\end{array}$ & $\begin{array}{l}0.169^{*} \\
(0.0854)\end{array}$ & $\begin{array}{l}0.0537 \\
(0.0744)\end{array}$ & $\begin{array}{l}0.0832 \\
(0.0744)\end{array}$ \\
\hline Parent Lost at Ages 2-5 & $\begin{array}{l}-0.182 \\
(0.100)\end{array}$ & $\begin{array}{l}-0.156 \\
(0.104)\end{array}$ & $\begin{array}{l}-0.0245 \\
(0.0600)\end{array}$ & $\begin{array}{l}-0.0128 \\
(0.0604)\end{array}$ & $\begin{array}{l}-0.0530 \\
(0.0501)\end{array}$ & $\begin{array}{l}-0.0352 \\
(0.0507)\end{array}$ \\
\hline Parent Lost at Ages 6-10 & $\begin{array}{c}-0.0879 \\
(0.0699)\end{array}$ & $\begin{array}{l}-0.0583 \\
(0.0724)\end{array}$ & $\begin{array}{l}-0.0118 \\
(0.0458)\end{array}$ & $\begin{array}{l}0.0122 \\
(0.0461)\end{array}$ & $\begin{array}{l}-0.0288 \\
(0.0375)\end{array}$ & $\begin{array}{l}-0.00102 \\
(0.0379)\end{array}$ \\
\hline Parent Lost at Ages 11-15 & $\begin{array}{c}-0.0182 \\
(0.0473)\end{array}$ & $\begin{array}{l}0.000341 \\
(0.0484)\end{array}$ & $\begin{array}{l}-0.0219 \\
(0.0329)\end{array}$ & $\begin{array}{c}-0.00453 \\
(0.0328)\end{array}$ & $\begin{array}{l}-0.0227 \\
(0.0267)\end{array}$ & $\begin{array}{c}-0.00538 \\
(0.0268)\end{array}$ \\
\hline $\operatorname{sex}(1=$ female $)$ & & $\begin{array}{l}0.409^{* * *} \\
(0.0140)\end{array}$ & & $\begin{array}{l}0.472^{* * *} \\
(0.0104)\end{array}$ & & $\begin{array}{l}0.452^{* * *} \\
(0.00872)\end{array}$ \\
\hline Controls (Birth Year / Birth County) & No & Yes & No & Yes & No & Yes \\
\hline $\mathrm{N}$ & 120489 & 120489 & 232790 & 232789 & 316385 & 316384 \\
\hline adj. R-sq & 0.000 & 0.026 & 0.000 & 0.033 & 0.000 & 0.030 \\
\hline
\end{tabular}

Source: Authors' calculations with data from Statistics Sweden (SCB)

Note: Heteroskedasticity-robust standard errors in parentheses. Where indicated, the models control for the individual's sex, birth year, and birth county. Inclusion in the model is conditional on observing a parental death, and on having a sibling (same mother ID) on a different age-category.

${ }^{*} \mathrm{p}<0.05,{ }^{* *} \mathrm{p}<0.01,{ }^{* * *} \mathrm{p}<0.001$ 
Table 14: Effect on Adult Hospitalizations of Losing a Parent in Early Life, relative to losing a Parent after age 16: Sibling-Approach

\begin{tabular}{|c|c|c|c|c|c|c|}
\hline \multirow[t]{2}{*}{ Parent Lost: } & \multicolumn{2}{|c|}{ Mother } & \multicolumn{2}{|c|}{ Father } & \multicolumn{2}{|c|}{ Any } \\
\hline & $(1)$ & $(2)$ & $(3)$ & $(4)$ & $(5)$ & $(6)$ \\
\hline Parent Lost at Ages 0-1 & $\begin{array}{l}-0.969 \\
(1.050)\end{array}$ & $\begin{array}{l}0.686 \\
(1.056)\end{array}$ & $\begin{array}{l}-0.381 \\
(0.472)\end{array}$ & $\begin{array}{l}0.324 \\
(0.475)\end{array}$ & $\begin{array}{l}-0.444 \\
(0.420)\end{array}$ & $\begin{array}{l}0.332 \\
(0.423)\end{array}$ \\
\hline Parent Lost at Ages 2-5 & $\begin{array}{c}-0.483 \\
(0.571)\end{array}$ & $\begin{array}{l}0.763 \\
(0.602)\end{array}$ & $\begin{array}{l}-0.110 \\
(0.344)\end{array}$ & $\begin{array}{l}0.462 \\
(0.353)\end{array}$ & $\begin{array}{l}-0.233 \\
(0.292)\end{array}$ & $\begin{array}{l}0.395 \\
(0.300)\end{array}$ \\
\hline Parent Lost at Ages 6-10 & $\begin{array}{c}-0.906^{*} \\
(0.373)\end{array}$ & $\begin{array}{l}0.0111 \\
(0.393)\end{array}$ & $\begin{array}{l}-0.346 \\
(0.257)\end{array}$ & $\begin{array}{l}0.106 \\
(0.262)\end{array}$ & $\begin{array}{c}-0.516^{*} \\
(0.210)\end{array}$ & $\begin{array}{c}-0.0117 \\
(0.215)\end{array}$ \\
\hline Parent Lost at Ages 11-15 & $\begin{array}{c}-0.383 \\
(0.276)\end{array}$ & $\begin{array}{l}0.117 \\
(0.284)\end{array}$ & $\begin{array}{c}-0.394^{*} \\
(0.159)\end{array}$ & $\begin{array}{l}-0.106 \\
(0.162)\end{array}$ & $\begin{array}{l}-0.410^{* *} \\
(0.141)\end{array}$ & $\begin{array}{l}-0.110 \\
(0.143)\end{array}$ \\
\hline $\operatorname{sex}(1=$ female $)$ & & $\begin{array}{l}1.473^{* * *} \\
(0.101)\end{array}$ & & $\begin{array}{l}1.293^{* * *} \\
(0.0610)\end{array}$ & & $\begin{array}{l}1.383^{* * *} \\
(0.0537)\end{array}$ \\
\hline Controls (Birth Year / Birth County) & No & Yes & No & Yes & No & Yes \\
\hline $\mathrm{N}$ & 82832 & 82832 & 160058 & 160057 & 216971 & 216970 \\
\hline adj. R-sq & 0.000 & 0.018 & 0.000 & 0.016 & 0.000 & 0.017 \\
\hline
\end{tabular}

Source: Authors' calculations with data from Statistics Sweden (SCB)

Note: Heteroskedasticity-robust standard errors in parentheses. Where indicated, the models control for the individual's sex, birth year, and birth county. Inclusion in the model is conditional on observing a parental death, and on having a sibling (same mother ID) on a different age-category.

$* \mathrm{p}<0.05, * * \mathrm{p}<0.01, * * * \mathrm{p}<0.001$ 
Table 15: Effect on Days of Hospitalization of Losing a Parent in Early Life, relative to losing a Parent after age 16: Sibling-Approach

\begin{tabular}{|c|c|c|c|c|c|c|}
\hline \multirow[t]{2}{*}{ Parent Lost: } & \multicolumn{2}{|c|}{ Mother } & \multicolumn{2}{|c|}{ Father } & \multicolumn{2}{|r|}{ Any } \\
\hline & $(1)$ & $(2)$ & $(3)$ & $(4)$ & $(5)$ & $(6)$ \\
\hline Parent Lost at Ages 0-1 & $\begin{array}{l}-16.40 \\
(15.39)\end{array}$ & $\begin{array}{l}2.100 \\
(17.98)\end{array}$ & $\begin{array}{l}49.89 \\
(41.78)\end{array}$ & $\begin{array}{l}57.34 \\
(43.66)\end{array}$ & $\begin{array}{l}32.27 \\
(28.45)\end{array}$ & $\begin{array}{l}42.34 \\
(30.20)\end{array}$ \\
\hline Parent Lost at Ages 2-5 & $\begin{array}{l}1.978 \\
(13.09)\end{array}$ & $\begin{array}{l}18.18 \\
(15.47)\end{array}$ & $\begin{array}{l}57.35 \\
(54.31)\end{array}$ & $\begin{array}{l}64.36 \\
(55.89)\end{array}$ & $\begin{array}{l}40.71 \\
(37.49)\end{array}$ & $\begin{array}{l}49.90 \\
(38.98)\end{array}$ \\
\hline Parent Lost at Ages 6-10 & $\begin{array}{l}-17.06 \\
(11.41)\end{array}$ & $\begin{array}{l}-5.863 \\
(12.77)\end{array}$ & $\begin{array}{l}25.10 \\
(25.12)\end{array}$ & $\begin{array}{l}29.80 \\
(26.38)\end{array}$ & $\begin{array}{l}12.44 \\
(16.71)\end{array}$ & $\begin{array}{l}18.91 \\
(17.87)\end{array}$ \\
\hline Parent Lost at Ages 11-15 & $\begin{array}{l}4.685 \\
(7.780)\end{array}$ & $\begin{array}{l}11.35 \\
(8.744)\end{array}$ & $\begin{array}{l}6.374 \\
(11.06)\end{array}$ & $\begin{array}{l}9.080 \\
(11.85)\end{array}$ & $\begin{array}{l}6.954 \\
(7.789)\end{array}$ & $\begin{array}{l}10.88 \\
(8.471)\end{array}$ \\
\hline $\operatorname{sex}(1=$ female $)$ & & $\begin{array}{c}-8.572 \\
(7.598)\end{array}$ & & $\begin{array}{l}-11.27^{*} \\
(4.922)\end{array}$ & & $\begin{array}{l}-6.984^{*} \\
(3.537)\end{array}$ \\
\hline Controls (Birth Year / Birth County) & No & Yes & No & Yes & No & Yes \\
\hline $\mathrm{N}$ & 82832 & 82832 & 160058 & 160057 & 216971 & 216970 \\
\hline adj. R-sq & 0.000 & 0.000 & 0.000 & 0.001 & 0.000 & 0.001 \\
\hline
\end{tabular}

Source: Authors' calculations with data from Statistics Sweden (SCB)

Note: Heteroskedasticity-robust standard errors in parentheses. Where indicated, the models control for the individual's sex, birth year, and birth county. Inclusion in the model is conditional on observing a parental death, and on having a sibling (same mother ID) on a different age-category.

${ }^{*} \mathrm{p}<0.05,{ }^{* *} \mathrm{p}<0.01,{ }^{* * *} \mathrm{p}<0.001$ 
Table 16: Effect on Mental Health Hospitalizations of Losing a Parent in Early Life, relative to losing a Parent after age 16: Sibling-Approach

\begin{tabular}{|c|c|c|c|c|c|c|}
\hline \multirow[t]{2}{*}{ Parent Lost: } & \multicolumn{2}{|c|}{ Mother } & \multicolumn{2}{|c|}{ Father } & \multicolumn{2}{|c|}{ Any } \\
\hline & (1) & $(2)$ & $(3)$ & $(4)$ & $(5)$ & $(6)$ \\
\hline Parent Lost at Ages 0-1 & $\begin{array}{l}-15.29 \\
(11.91)\end{array}$ & $\begin{array}{l}-9.484 \\
(7.925)\end{array}$ & $\begin{array}{l}1.782 \\
(1.744)\end{array}$ & $\begin{array}{l}2.251 \\
(1.977)\end{array}$ & $\begin{array}{l}-2.100 \\
(2.750)\end{array}$ & $\begin{array}{l}-0.533 \\
(2.611)\end{array}$ \\
\hline Parent Lost at Ages 2-5 & $\begin{array}{l}-0.173 \\
(3.528)\end{array}$ & $\begin{array}{l}2.662 \\
(3.897)\end{array}$ & $\begin{array}{l}2.377 \\
(1.654)\end{array}$ & $\begin{array}{l}2.369 \\
(1.782)\end{array}$ & $\begin{array}{l}1.101 \\
(1.533)\end{array}$ & $\begin{array}{l}2.133 \\
(1.687)\end{array}$ \\
\hline Parent Lost at Ages 6-10 & $\begin{array}{l}-2.755 \\
(2.084)\end{array}$ & $\begin{array}{l}-0.477 \\
(2.404)\end{array}$ & $\begin{array}{l}4.571^{*} \\
(1.862)\end{array}$ & $\begin{array}{l}4.404^{*} \\
(1.942)\end{array}$ & $\begin{array}{l}1.190 \\
(1.296)\end{array}$ & $\begin{array}{l}2.045 \\
(1.388)\end{array}$ \\
\hline Parent Lost at Ages 11-15 & $\begin{array}{l}-0.334 \\
(1.617)\end{array}$ & $\begin{array}{l}0.619 \\
(1.814)\end{array}$ & $\begin{array}{l}1.105 \\
(1.452)\end{array}$ & $\begin{array}{l}1.100 \\
(1.521)\end{array}$ & $\begin{array}{l}0.0412 \\
(1.069)\end{array}$ & $\begin{array}{l}0.592 \\
(1.143)\end{array}$ \\
\hline $\operatorname{sex}(1=$ female $)$ & & $\begin{array}{l}0.568 \\
(0.833)\end{array}$ & & $\begin{array}{l}-0.735 \\
(0.718)\end{array}$ & & $\begin{array}{l}0.0264 \\
(0.571)\end{array}$ \\
\hline Controls (Birth Year / Birth County) & No & Yes & No & Yes & No & Yes \\
\hline $\mathrm{N}$ & 5309 & 5309 & 9653 & 9652 & 13259 & 13258 \\
\hline adj. R-sq & 0.010 & 0.057 & 0.005 & 0.038 & 0.001 & 0.024 \\
\hline
\end{tabular}

Source: Authors' calculations with data from Statistics Sweden (SCB)

Note: Heteroskedasticity-robust standard errors in parentheses. Where indicated, the models control for the individual's sex, birth year, and birth county. Inclusion in the model is conditional on observing a parental death, and on having a sibling (same mother ID) on a different age-category.

${ }^{*} \mathrm{p}<0.05,{ }^{* *} \mathrm{p}<0.01,{ }^{* * *} \mathrm{p}<0.001$ 